BÁO CÁO CHUYÊN ĐÊ

\title{
Tác động kinh tế và xã hội của chi trả dịch vụ môi trường rừng tại Vườn Quốc Gia Cát Tiên
}

Phạm Thu Thủy

Đào Thị Linh Chi

Nguyễn Thanh Long

Hoàng Tuấn Long

Nguyễn Đình Thảo

Phạm Hồng Lượng

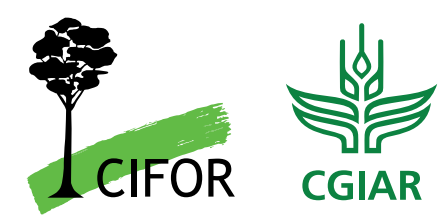





\section{Tác động kinh tế và xã hội của chi trả dịch vụ môi trường rừng tại Vườn Quốc Gia Cát Tiên}

Phạm Thu Thủy

CIFOR

Đào Thị Linh Chi

CIFOR

Nguyễn Thanh Long

Vườn Quốc Gia Cát Tiên

Hoàng Tuấn Long

CIFOR

Nguyễn Đình Thảo

CIFOR

Phạm Hồng Lượng

Vườn Quốc Gia Cát Tiên 
Báo cáo chuyên đề 215

C 2020 Tổ chức Nghiên cứu Lâm nghiệp Quốc tế (CIFOR)

Nội dung trong ấn phẩm này được cấp quyền bởi Giấy phép bản quyền Ghi nhận công của tác giả - Phi thương mại, không chỉnh sửa, thay đổi hay phát triển - Không phát sinh 4.0. http://creativecommons.org/ licenses/by-nc-nd/4.0/

ISBN: 978-602-387-149-0

DOI: $10.17528 /$ cifor/007892

Phạm TT, Đào TLC, Nguyễn TL, Hoàng TL, Nguyễn ĐT và Phạm HL. 2020. Tác động kinh tế và xã hội của chi trả dịch vụ môi trường rừng tại Vườn Quốc Gia Cát Tiên. Báo cáo chuyên đề 215. Bogor, Indonesia: CIFOR.

Ảnh được chụp bởi Binh Dang/GIZ.

Kiểm lâm viên của Vườn Quốc Gia Cát Tiên trên đường đi tuần tra rừng.

\section{CIFOR}

Jl. CIFOR, Situ Gede

Bogor Barat 16115

Indonesia

$\mathrm{T}+62(251) 8622-622$

$\mathrm{F}+62(251) 8622-100$

E cifor@cgiar.org

\section{cifor.org}

Chúng tôi xin cảm ơn các nhà tài trợ đã hỗ trợ cho nghiên cứu này thông qua việc đóng góp vào quỹ của CGIAR. Xin xem danh sách các nhà tài trợ: http://www.cgiar.org/about-us/our-funders/

Tất cả các quan điểm thể hiện trong ấn phẩm này là của các tác giả. Chúng không nhất thiết đại diện cho quan điểm của CIFOR, các cơ quan chủ quản của tác giả hay của các nhà tài trợ cho ấn phẩm này. 


\section{Mục lục}

Lời cảm ơn

Tóm tắt tổng quan

1 Mở đầu 1

2 Khung phân tích và phương pháp nghiên cứu 3

2.1 Khung phân tích 3

2.2 Phương pháp thu thập thông tin, số liệu 3

$\begin{array}{ll}2.3 \text { Hạn chế của nghiên cứu } & 6\end{array}$

3 Khái quát về VQG Cát Tiên và thực trạng chi trả DVMTR tại VQG Cát Tiên $\quad 8$

4 Tác động xã hội của PFES

4.1 Số hộ dân tộc thiểu số được nhận tiền chi trả DVMTR 12

4.2 Số hộ nghèo được nhận tiền chi trả DVMTR và số hộ thoát nghèo 12

4.3 Sự tham gia của người dân vào chương trình bảo vệ và phát triển rừng 13

5 Tác động kinh tế của PFES $\quad 15$

5.1 Diện tích giao khoán bảo vệ rừng cho người dân 15

5.2 Số HGD nhận khoán BVR/Số HGD được nhận tiên chi trả DVMTR 15

5.3 Số tiền nhận được trung bình trên một ngày công tuân tra bảo vệ rừng
được chi trả DVMTR

5.4 Tỉ trọng thu nhập từ PFES trong tổng thu nhập của hộ gia đình 19

6 Thảo luận và đề xuất $\quad 22$

6.1 Giải pháp thể chế và chính sách 22

6.2 Giải pháp hỗ trợ nguôn vốn xã hội 23

6.3 Giải pháp hỗ trợ nguôn vốn tài chính 23

7 Kết luận $\quad 25$

Tài liệu tham khảo 26 


\section{Danh mục hình và bảng}

\section{Hình}

1 Vị trí VQG Cát Tiên trên bản đồ Việt Nam

2 Dòng chảy tài chính của tiên DVMTR tại VQG Cát Tiên 9

3 Tổng diện tích cung ứng DVMTR tại VQG Cát Tiên 10

4 Diện tích tự bảo vệ và diện tích giao khoán cho người dân tại VQG Cát Tiên $\quad 10$

5 Phân bổ diện tích cung ứng tại VQG Cát Tiên 11

6 Tỷ lệ tự bảo vệ và khoán bảo vệ tại VQG Cát Tiên 11

7 Diện tích giao khoán cho người dân trước khi PFES 16

8 Diện tích giao khoán bảo vệ rừng cho cộng đông và hộ dân từ khi có PFES 16

9 Số cộng đồng và số hộ nhận khoán bảo vệ rừng tại VQG Cát Tiên 17

10 Thu nhập từ PFES qua các năm (Đơn vị: triệu VND) 18

11 Đơn giá chi trả DVMTR 19

12 Đơn giá chi trả DVMTR và quyết định 24 (chỉ áp dụng cho Đồng Nai) 19

13 Đóng góp của PFES vào tổng thu nhập năm $2019 \quad 20$

14 Nhận thức về vấn đề đảm bảo thu nhập cho cuộc sống trong 10 năm qua 20

\section{Bảng}

1 Chỉ số giám sát đánh giá tác động kinh tế và xã hội của PFES 4

2 Tên các thôn ấp được lựa chọn để tiến hành nghiên cứu 4

3 Tổng hợp số người tham gia họp nhóm thôn/ấp 5

4 Thông tin về phỏng vấn sâu hộ gia đình 6

5 Tỷ lệ số hộ dân tộc thiểu số nhận được tiền DVMTR 2019

6 Tỷ lệ hộ nghèo nhận được DVMTR trong các thôn ấp 13

7 Số cộng đồng và số hộ tham gia DVMTR phân theo từng tỉnh 16

8 Tỷ lệ số hộ nhận tiền DVMTR 17

9 Mức chi trả tiền khoán bảo vệ rừng trước và sau PFES 18 


\section{Lời cảm ơn}

Nghiên cứu này là một phần của Nghiên cứu So sánh Toàn cầu của CIFOR về REDD + (www.cifor. org/gcs). Các đối tác tài trợ đã hỗ trợ nghiên cứu này bao gồm Cơ quan Hợp tác Phát triển $\mathrm{Na} \mathrm{Uy}$ (NORAD), Sáng kiến Khí hậu Quốc tế (IKI) của Bộ Môi trường, Bảo tồn Thiên nhiên, Xây dựng và An toàn Hạt nhân Liên bang Đức (BMUB) và Chương trình Nghiên cứu CGIAR vê Rừng, Cây và Nông lâm kết hợp (CRP-FTA) với sự hỗ trợ tài chính từ các Nhà tài trợ Quỹ CGIAR.

Chúng tôi xin gửi lời cảm ơn chân thành tới ông Phạm Hữu Khánh - Trưởng Phòng Khoa học và Hợp tác quốc tế Vườn quốc gia Cát Tiên cũng như các cán bộ của Vườn quốc gia Cát Tiên đã tham gia vào nghiên cứu này. Chúng tôi cũng xin cảm ơn bà Ngô Hà Châu, ông Hoàng Minh Hiếu, bà Hoàng Thị Uyên và bà Hoàng Thị Thu Thủy đã hỗ trợ nhóm nghiên cứu trong việc tổng hợp số liệu.

Chúng tôi cũng xin gửi lời cảm ơn tới các đại biểu đã tham dự hội thảo tại Vườn quốc gia Cát Tiên và Hội thảo quốc gia về PFES với những ý kiến đóng góp quý báu đã giúp chúng tôi hoàn thiện báo cáo. 


\section{Tóm tắt tổng quan}

Nhằm bảo vệ diện tích rừng hiện có, nâng cao chất lượng rừng, gia tăng đóng góp của ngành Lâm nghiệp vào nền kinh tế quốc dân, giảm nhẹ gánh nặng lên ngân sách Nhà nước cho việc đâu tư vào ngành Lâm nghiệp và đảm bảo an sinh xã hội của người làm nghể rừng, Chính phủ Việt Nam đã quyết định thông qua cơ chế tài chính mới để huy động nguôn lực cho ngành Lâm nghiệp, đó là chính sách chi trả dịch vụ môi trường rừng - PFES. Mặc dù PFES được kì vọng sẽ giúp nhiều vườn quốc gia trên cả nước trong công tác bảo vệ phát triển rừng, có rất ít các bằng chứng khoa học được đưa ra để khẳng định tính hiệu quả của PFES trong lĩnh vực này. Sử dụng trường hợp nghiên cứu điểm tại Vườn Quốc Gia Cát Tiên, báo cáo này thảo luận tác động kinh tế và xã hội của chính sách Chi trả dịch vụ môi trường rừng (PFES) đối với các Vườn Quốc Gia tại Việt Nam.

Việc chọn VQG Cát Tiên làm nghiên cứu điểm có nhiêu ý nghĩa. Thứ nhất, VQG Cát Tiên là một trong những chủ rừng lớn nhất thuộc Tổng cục Lâm nghiệp Việt Nam (VNFOREST), có diện tích $82,597.4^{1}$ ha nằm trong địa bàn của 3 tỉnh: Đông Nai, Lâm Đông và Bình Phước. Thứ hai, từ năm 2010 đến nay, VQG Cát Tiên đã nhận được tổng số khoảng hơn 100 tỷ đồng từ PFES, là một trong những VQG có thu nhập lớn nhất cả nước từ PFES. Đánh giá tác động của PFES tại VQG Cát Tiên sẽ cung cấp những bằng chứng khoa học quý giá giúp các nhà hoạch định chính sách cập nhật toàn diện hơn về hiệu quả của PFES đối với các VQG. Nghiên cứu áp dụng một khung phân tích tính bổ sung của chính sách thông qua việc so sánh trước và sau khi có PFES tại nơi có

1 "Trong nghiên cứu này, dấu phẩy "," dùng để phân cách hàng nghìn, còn dấu chấm "." dùng để phân cách thập phân" và không có PFES. 4 cặp thôn được chọn để làm nghiên cứu so sánh giữa những nơi có và không có PFES. Nhóm nghiên cứu cũng tiến hành thu thập và phân tích số liệu thứ cấp, phỏng vấn sâu với 244 hộ gia đình hộ gia đình (123 hộ ở nơi có PFES và 121 hộ ở nơi không có PFES).

Kết quả cho thấy những tác động tích cực về mặt xã hội và kinh tế đối với cộng đồng dân cư tại địa bàn Vườn Quốc Gia Cát Tiên. Cụ thể hơn, từ $50 \%$ tới $92 \%$ người tham gia phỏng vấn là người dân tộc thiểu số được tham gia và hưởng lợi trực tiếp từ PFES. Tại các thôn có PFES, số lượng hộ nghèo được tham gia DVMTR trên tổng số hộ nghèo trong thôn chiếm tỷ lệ từ $45 \%$ và cao nhất là $88 \%$. Trong tổng số hộ nghèo tham gia DVMTR tại các thôn nghiên cứu, $22 \%$ không có nguôn thu nhập bằng tiền mặt nào khác ngoài tiền khoán bảo vệ rừng và $81.4 \%$ số hộ nghèo này khi có thêm tiền khoán bảo vệ rừng thì đã thoát nghèo (chiếm 81.4\% tổng số hộ nghèo tham gia DVMTR).

Trước khi có $\mathrm{PFES}$, diện tích rừng được giao khoán bảo vệ rừng tại VQG Cát Tiên chỉ là 8,851 hecta, chiếm tỉ trọng $12 \%$ tổng diện tích rừng của VQG Cát Tiên. Tuy nhiên, sau khi có PFES, diện tích rừng được giao cho cộng đồng và hộ gia đình quản lí gấp 3 tới 3.64 lần so với trước khi có PFES. Diện tích do người dân quản lí bảo vệ rừng thông qua khoán bảo vệ sau khi có PFES cũng chiếm tỉ trọng cao hơn trước khi có PFES, từ 37\%-39\% tổng diện rừng của VQG quản lí. Tuy số lượng cộng đông nhận khoán không thay đổi trước và sau DVMTR nhưng số lượng hộ dân tham gia khoán bảo vệ rừng từ khi có DVMTR giảm hơn hẳn so với trước khi có DVMTR. PFES đang đóng góp từ $8 \%$ cho tới $100 \%$ trong tổng thu nhập của hộ gia đình tại 4 thôn nghiên cứu. 
Tính trung bình, PFES đóng góp từ 16\% cho tới $74 \%$ trong tổng thu nhập của hộ gia đình tại các thôn có PFES. Thu nhập của các điểm có PFES cao hơn hẳn so với nơi không có PFES.

Sau 10 năm thực hiện, Chính sách chi trả DVMTR đã tạo ra các tác động tích cực về mặt kinh tế và xã hội với phần lớn hộ tham gia khảo sát trong nghiên cứu này. Tuy nhiên, để nâng cao hiệu quả của chính sách PFES cần có cơ chế chia sẻ lợi ích phù hợp, thúc đẩy sự tham gia của người dân đồng thời hài hòa hóa với các chính sách phát triển kinh tế xã hội khác. Nghiên cứu này đã giải quyết phần nào lỗ hổng kiến thức được đề cập và đưa ra các bằng chứng khoa học hiện có để chứng minh tác động thực sự của chi trả DVMTR đối với cải thiện sinh kế của hộ gia đình tại Vườn Quốc Gia Cát Tiên. Tuy nhiên, báo cáo này vẫn còn một số hạn chế nhất định như sự thiếu hụt trong tài liệu và số liệu liên quan đến chi trả DVMTR, việc chọn cặp thôn nghiên cứu chưa đạt được điều kiện lý tưởng nhất, nguôn lực tài chính và con người có hạn. Chính vì vậy, nhóm nghiên cứu hi vọng các nghiên cứu trong tương lai có thể xây dựng dựa trên cả kết quả và hạn chế của nghiên cứu này để tiếp tục hoàn thiện quá trình đánh giá tác động của chính sách. 


\section{Danh mục từ viết tắt}

$\begin{array}{ll}\text { BQLR } & \text { Ban Quản lý Rừng } \\ \text { BVPTR } & \text { Bảo vệ Phát triển Rừng } \\ \text { BVR } & \text { Bảo vệ Rừng } \\ \text { CIFOR } & \text { Tổ chức nghiên cứu Lâm nghiệp Quốc tế } \\ \text { DVMTR } & \text { Dịch vụ môi trường rừng } \\ \text { HGD } & \text { Hộ gia đình } \\ \text { NN\&PTNT } & \text { Nông nghiệp và Phát triển Nông thôn } \\ \text { PES } & \text { Chi trả Dịch vụ môi trường } \\ \text { PFES } & \text { Chi trả Dịch vụ môi trường rừng } \\ \text { VNFF } & \text { Quỹ Bảo vệ phát triển rừng Việt Nam } \\ \text { VNFOREST } & \text { Tổng cục Lâm nghiệp } \\ \text { VQG } & \text { Vườn quốc gia }\end{array}$




\section{Mở đầu}

Nhằm bảo vệ diện tích rừng hiện có, nâng cao chất lượng rừng, gia tăng đóng góp của ngành lâm nghiệp vào nền kinh tế quốc dân, giảm nhẹ gánh nặng lên ngân sách Nhà nước cho việc đâu tư vào ngành lâm nghiệp và đảm bảo an sinh xã hội của người làm nghề rừng, Chính phủ Việt Nam đã quyết định thông qua cơ chế tài chính mới để huy động nguôn lực cho ngành lâm nghiệp đó là chính sách chi trả dịch vụ môi trường rừng (DVMTR) - PFES (Phạm và cộng sự., 2013; Phạm Hồng Lượng, 2018; Nguyễn Bá Ngãi, 2020). Chi trả dịch vụ môi trường rừng (PFES) được chính phủ Việt Nam đánh giá là một trong 10 thành tựu lớn nhất của ngành nông lâm nghiệp Việt Nam trong giai đoạn 2010 - 2020. Theo báo cáo của Quỹ Bảo vệ và Phát triển rừng Việt Nam năm 2020, PFES đã đóng góp $28.1 \%$ vào năm 2019 và $26.4 \%$ vào tháng 11 năm 2020 trong tổng lượng đầu tư cho ngành lâm nghiệp (Nguyễn Chiến Cường, 2020). Cũng theo báo cáo này, số tiền thu được từ PFES năm 2019 bằng $164.2 \%$ và năm 2020 bằng $143.9 \%$ tổng ngân sách nhà nước đầu tư cho ngành lâm nghiệp.

Mặc dù có nhiều các nghiên cứu đánh giá tác động PFES tại Việt Nam (ví dụ: Tran và cộng sự., 2016; Trædal \& Vedeld, 2017; Duong \& de Groot, 2018; Duong \& de Groot, 2020) nhưng các nghiên cứu này đều ở quy mô nhỏ không mang tính đại diện và phương pháp áp dụng đánh giá không chính xác và không đây đủ (Phạm Thu Thủy và cộng sự, 2018a; Pham và cộng sự, 2020). Điểm mấu chốt của việc đánh giá tác động của PFES là phải chứng minh được tính bổ sung của chính sách này. Cụ thể hơn, chất lượng rừng, diện tích rừng, điều kiện sống của hộ gia đình có được cải thiện hơn khi so sánh trước và sau khi có $\mathrm{PFES}$, ở nơi có và không có $\mathrm{PFES}$ ? Phần lớn các nghiên cứu cho tới nay chỉ đánh giá tác động trước và sau khi có PFES mà không sử dụng điểm đối chứng để chỉ rõ tính bổ sung của PFES. Điều này gây ra nhiêu khó khăn đối với các nhà hoạch định chính sách trong việc xác định tác động thực sự của PFES.

Nhằm giải quyết khoảng trống kiến thức này, báo cáo xác định tác động kinh tế và xã hội mà PFES đem lại cho cộng đồng dân cư sống xung quanh Vườn Quốc Gia Cát Tiên và thảo luận các để xuất chính sách để nâng cao hiệu quả thực thi chính sách PFES.

Nghiên cứu này nằm trong khuôn khổ hợp tác giữa Tổ chức nghiên cứu Lâm nghiệp Quốc tế (CIFOR) và Vườn Quốc Gia Cát Tiên trong việc đánh giá tác động của PFES tại VQG này. Báo cáo sẽ tập trung vào việc đánh giá tác động của PFES dựa trên mục tiêu đề ra của chính sách và bám sát theo khung pháp lí vê giám sát đánh giá của PFES do Bộ NN\&PTNT quy định. Theo Nghị định 99, PFES có 3 mục tiêu chính: i) nâng cao chất lượng và số lượng của dịch vụ môi trường rừng; (ii) cải thiện sinh kế của người dân; và (iii) huy động nguồn ngân sách bền vững cho ngành lâm nghiệp. Tuy nhiên, báo cáo này chỉ tập trung vào việc đánh giá tác động kinh tế và xã hội của PFES.

PFES được thực hiện tại 45 tỉnh thành trên cả nước nhưng nguôn thu lớn từ PFES (trên 50 tỉ một năm) tập trung chủ yếu vào các tỉnh miền núi phía Bắc và các tỉnh có diện tích rừng lớn nằm trong các Vườn Quốc Gia (VQG) (Phạm Thu Thủy và cộng sự, 2018a). Tuy nhiên có rất ít các nghiên cứu đánh giá hiệu quả của PFES đối với các cộng đông dân cư sống tại vùng đệm và vùng lõi của các VQG. Ngoài một số nghiên cứu nhỏ tại VQG Bạch Mã (ví dụ như nghiên cứu của Haas và cộng sự., 2019), chưa có một nghiên cứu bài bản áp dụng các phương pháp nghiên cứu chính xác để đánh giá tác động PFES ở bất kì một VQG nào tại Việt Nam. Vì vậy nghiên cứu này tiến hành tại VQG Cát Tiên sẽ rất có ý nghĩa bởi những lí do sau. Thứ nhất, VQG Cát Tiên là một trong những chủ rừng lớn nhất thuộc Tổng cục 
Lâm nghiệp Việt Nam (VNFOREST), có diện tích 82.597,4ha nằm trên địa bàn của 3 tỉnh: Đông Nai, Lâm Đông và Bình Phước. VQG Cát Tiên có một hệ sinh thái điển hình cho khu vực Đông Nam Bộ với hệ động thực vật phong phú và đa dạng. VQG Cát Tiên được UNESCO công nhận là Khu dự trũ̃ sinh quyển thế giới thứ 411 vào năm 2001 và đang được Bộ NN\&PTNT coi là một trong những ưu tiên hàng đâuu vể bảo tôn của Việt Nam. Thứ hai, từ năm 2010 đến nay,
VQG Cát Tiên đã nhận được 100 tỷ đồng từ PFES, là một trong những VQG có nguồn thu lớn nhất cả nước từ PFES. Thứ ba, việc thực hiện PFES tại Cát Tiên đã đem tới nguôn lợi tài chính cho 1,263 hộ gia đình, 44 cộng đồng. Việc đánh giá tác động của PFES tại VQG Cát Tiên sẽ có ý nghĩa trong việc ghi nhận và phân tích các tác động của PFES đối với đời sống của người dân nói riêng và công tác bảo tôn nói chung. 


\section{Khung phân tích và phương pháp nghiên cứu}

\subsection{Khung phân tích}

Trong nghiên cứu này, nhóm nghiên cứu kết hợp và sử dụng hai khung phân tích khác nhau.

Khung phân tích tính bổ sung của chính sách: Khi đánh giá tác động của $\mathrm{PES}$ và $\mathrm{PFES}$, nhiều học giả đã áp dụng khung phân tích tính bổ sung của chính sách, cụ thể phân tích sự khác biệt về kết quả đâu ra của chính sách PFES so với đường cơ sở trong trường hợp không có PFES cũng như so sánh trước và sau khi có PES (Angelsen, 2017; Le Velly \& Dutilly, 2016; Naeem và cộng sự.., 2015; Wunder, 2005; Sunderlin \& Sill, 2012). Khung phân tích này tập trung so sánh tác động của DVMTR trước và sau khi có DVMTR, ở nơi có sự can thiệp của DVMTR (can thiệp) và nơi không có DVMTR (đối chứng) và được cộng đông cộng đông quốc tế sử dụng rộng rãi (Bos, 2020).

Khung giám sát và đánh giá theo hướng dẫn của Quỹ bảo vệ phát triển rừng Việt Nam: Khác với các chương trình dự án đơn lẻ, DVMTR là một chương trình chính sách Quốc gia do đó Chính Phủ đã xây dựng hành lang pháp lí để giám sát, theo dõi và đánh giá tác động DVMTR. Để thực hiện công tác giám sát và đánh giá cho $\mathrm{PFES}$, Bộ Nông Nghiệp và Phát Triển Nông Thôn đã tiến hành rà soát tài liệu quốc tế về cơ chế giám sát PFES, xây dựng và thí điểm các chỉ số và cơ chế giám sát tại nhiều địa phương sau đó tổng kết thành hướng dẫn quốc gia về giám sát và đánh gia PFES. Bộ chỉ số giám sát đánh giá đã góp phân giải quyết khoảng trống lớn về hệ thống thông tin, dũ liệu phục vụ cho báo cáo và giải trình giữa các cấp, giữa các bên liên quan, nhất là giữa bên cung ứng DVMTR với bên sử dụng DVMTR. Chỉ số đánh giá giám sát do Quỹ Bảo vệ phát triển rừng Trung ương (VNFF) xây dựng bao gồm 28 chỉ số về thể chế, kinh tế, xã hội và môi trường. Tuy nhiên trong khuôn khổ nghiên cứu và báo cáo này, chúng tôi chỉ đánh giá một số tiêu chí theo hướng dẫn của VNFF quy định (Bảng 1). Cụ thể hơn, nghiên cứu đánh giá sự thay đổi của các chỉ số này trước và sau khi có DVMTR, ở nơi có và không có DVMTR.

\subsection{Phương pháp thu thập thông tin, số liệu}

Lựa chọn năm cơ sở. Để có thể đánh giá tác động của PFES bằng cách so sánh trước và sau khi có PFES, nhóm nghiên cứu xác định năm cơ sở để so sánh đóng vai trò quan trọng. VQG Cát Tiên nằm trên địa giới của tỉnh Lâm Đồng, Đông Nai và Bình Phước. Do mỗi tỉnh lại thực hiện PFES ở các thời điểm khác nhau nên năm cơ sở tại mỗi tỉnh cũng có sự khác biệt. DVMTR được thực hiện tại Lâm Đông vào năm 2010 và Đồng Nai và Bình Phước vào năm 2014 nên ở Lâm Đồng sẽ chọn 2010 và Đông Nai và Bình Phước chọn 2014 làm mốc để so sánh trước và sau khi có $D V M T R$ tại VQG Cát Tiên.

Lựa chọn địa bàn nghiên cứu. Để có thể so sánh được tác động rõ rệt của DVMTR, nhóm nghiên cứu của CIFOR phối hợp với VQG Cát Tiên tiến hành việc chọn lựa các cặp thôn bản có điều kiện tương đối giống nhau giữa các thôn ấp có DVMTR và thôn ấp không có DVMTR. Áp dụng phương pháp đã được phát triển bởi Sunderlin \& Sill (2012), nghiên cứu này đã lựa chọn 4 cặp thôn (thôn có DVMTR - thôn không có DVMTR), so sánh trước và sau khi có DVMTR (Bảng 2) để có thể so sánh được tác động rõ rệt của DVMTR. Việc lựa chọn 4 cặp với 30 hộ phỏng vấn mỗi thôn theo hướng dẫn chung của Sunderlin và cộng sự. (2016) nhằm đảm bảo sự chính xác của các phân tích thống kê. Việc lựa chọn các cặp nghiên cứu này này được tiến hành qua các bước như sau:

- Bước 1: Nhóm nghiên cứu rà soát tài liệu thứ cấp và tham vấn với chính quyền địa phương 
Bảng 1. Chỉ số giám sát đánh giá tác động kinh tế và xã hội của PFES

Chỉ số giám sát đánh giá về xã hội và kinh tế

Tác động xã hội của PFES

- Số tiền và số lượng các công trình, trang thiết bị và hoạt động phúc lợi cộng đồng được xây dựng từ tiền DVMTR

- Tỷ lệ số tiền DVMTR trong tổng số chi phí xây dựng nông thôn mới

- Số lượt người được đào tạo tập huấn về công tác bảo vệ rừng và chi trả DVMTR

Tác động kinh tế của PFES

- Số HGD nhận khoán BVR

- Tỷ lệ số hộ được nhận tiền DVMTR đi tuần tra BVR so với tổng số hộ dân trên địa bàn

- Số tiền nhận được trung bình trên một ngày công tuần tra bảo vệ rừng được chi trả DVMTR

- Tổng số HGD, cá nhân được nhận tiền chi trả DVMTR

- Số hộ dân tộc thiểu số được nhận tiền chi trả DVMTR

- Số hộ nghèo được nhận tiền chi trả DVMTR

- Số lượng hộ nhận khoán BVR thoát nghèo hàng năm

Chỉ số giám sát đánh giá về thể chế chính sách

Tuyên truyền, phổ biến chính sách Tỷ lệ người dân hiểu biết về chính sách chi trả DVMTR

Nguồn: VNFF, 2020

Bảng 2. Tên các thôn ấp được lựa chọn để tiến hành nghiên cứu

\begin{tabular}{|c|c|c|c|c|}
\hline STT & Tên thôn ấp & Tỉnh & Có DVMTR & Không DVMTR \\
\hline \multirow[t]{2}{*}{1} & Ấp A, xã Đắc Lua & Đồng Nai & $x$ & \\
\hline & Thôn B, xã Đăng Hà & Bình Phước & & $x$ \\
\hline \multirow[t]{2}{*}{2} & Thôn C, xã Gia Viễn & Lâm Đồng & $x$ & \\
\hline & Ấp D, xã Tà Lài & Đồng Nai & & $x$ \\
\hline \multirow[t]{2}{*}{3} & Thôn E, xã Tiên Hoàng & Lâm Đồng & $x$ & \\
\hline & Ấp F, xã Đắc Lua & Đồng Nai & & $x$ \\
\hline \multirow[t]{2}{*}{4} & Thôn G, xã Phước Cát 2 & Lâm Đồng & $x$ & \\
\hline & Thôn H, xã Phước Sơn & Bình Phước & & $x$ \\
\hline
\end{tabular}

* Các thôn trong nghiên cứu đã được ẩn tên

về điều kiện kinh tế xã hội của địa phương, các nguyên nhân dẫn đến phá rừng và suy thoái rừng, các nhóm chủ rừng và đối tượng nhận khoán, các nhóm nhận được tiền chi trả dịch vụ môi trường rừng, diễn biến tài nguyên rừng qua từng năm, khả năng tiếp cận tới thôn (ví dụ địa bàn không quá khó khăn về mặt địa lí nhóm nghiên cứu có thể tới được, tình hình an ninh ổn định nhóm nghiên cứu có thể tiến hành nghiên cứu) để lên một danh sách 15 cặp thôn bản có thể tiến hành nghiên cứu. Các cặp thôn bản này phải có điều kiện kinh tế, chính trị xã hội tương đồng nhưng bản sẽ có DVMTR và bản không có DVMTR. Trong thực tế không có các cặp giống nhau hoàn toàn, nhưng nhóm nghiên cứu chọn các điểm nghiên cứu có độ giống nhau nhất có thể.
- Bước 2: Tiến hành điều tra trên thực địa để đảm bảo các cặp thôn bản được lựa chọn thể hiện đúng tiêu chí nghiên cứu.

- Bước 3: Dựa vào sự đông thuận của người dân và chính quyên địa phương cho phép tiến hành nghiên cứu trên địa bàn và rà soát sau bước 2 , nhóm nghiên cứu ghép lại các cặp bản và chọn ra 4 cặp bản giống nhau nhau để tiến hành thu thập số liệu. Bảng 3 trình bày kết quả lựa chọn 4 cặp thôn bản nghiên cứu.

Có thể thấy các cặp thôn bản không nằm trong cùng một tỉnh nhưng được lựa chọn bởi nghiên cứu này đánh giá dựa vào phương pháp quy mô cảnh quan rừng mà VQG Cát Tiên đang quản lí. Kết quả kiểm chứng trên thực địa cũng đã khẳng định phần lớn các điều kiện của các cặp này là giống nhau. 
Nghiên cứu tài liệu thứ cấp. Nhóm nghiên cứu rà soát lại tài liệu thứ cấp về chính sách DVMTR trên thế giới, tại Việt Nam cũng như tại địa bàn nghiên cứu bao gồm các báo cáo của VQG Cát Tiên, Quỹ BVPTR tỉnh, báo cáo của các sở ban ngành trong tỉnh, kế hoạch phát triển kinh tế xã hội của tỉnh - huyện - xã - thôn ấp, các báo cáo khoa học của các bên có liên quan cũng như các nghiên cứu đã thực hiện đánh giá tác động của chính sách chi trả DVMTR.

Thu thập số liệu sơ cấp. Nhóm nghiên cứu đã tiến hành nhiều phương pháp để thu thập số liệu thứ cấp:

- Họp nhóm thôn bản. Tại mỗi bản, thảo luận nhóm tập trung được tiến hành với 2 nhóm: nhóm nam và nhóm nữ. Các hộ gia đình tham gia vào thảo luận nhóm được dựa trên tiêu chí đại diện về lứa tuổi, giới tính, thu nhập, dân tộc, kinh nghiệm tham gia vào DVMTR. Tổng số có 149 người đã tham gia vào thảo luận nhóm chuyên sâu (70 nam và 79 nữ) (Bảng 3 ). Các thảo luận này tập trung vào lịch sử hình thành thôn bản, nguyên nhân dẫn đến phá rừng và suy thoái rừng, phân loại kinh tế hộ, điểm mạnh, điểm yếu và đóng góp, tác động của DVMTR hay các chương trình hỗ trợ tại địa phương đối với đời sống người dân cũng như mong muốn của người dân về việc thực hiện các chương trình hỗ trợ phát triển hiệu quả hơn.
- Phỏng vấn các bên có liên quan. Nhóm nghiên cứu tiến hành phỏng vấn các bên liên quan thực hiện DVMTR từ cấp tỉnh, cấp huyện cho đến cấp xã (37 cuộc phỏng vấn đã được thực hiện). Các cuộc phỏng vấn này nhằm tìm hiểu quan điểm của các bên có liên quan về tác động của DVMTR cũng như khó khăn thuận lợi khi thực hiện DVMTR trên địa bàn.

- Phỏng vấn hộ gia đình. Nhóm nghiên cứu của Tổ chức nghiên cứu lâm nghiệp quốc tế CIFOR và cán bộ VQG Cát Tiên tiến hành phỏng vấn sâu 244 hộ gia đình ở 8 thôn bản trong đó những thôn có DVMTR là 123 hộ, những thôn không DVMTR là 121 hộ (Bảng 4). Số hộ được tham gia DVMTR trong 123 hộ tại thôn có DVMTR là 46 hộ, chiếm $37 \%$. Các phỏng vấn này nhằm tìm hiểu sinh kế và điều kiện sống của người dân, quan điểm của người dân về tác động của DVMTR và những thuận lợi và khó khăn khi tham gia DVMTR, cũng như những đề xuất để thực hiện DVMTR hiệu quả hơn trong tương lai.

- Hội thảo tham vấn. Kết quả nghiên cứu này đã được trình bày trong hội thảo tham vấn tại VQG Cát Tiên và tại Hội thảo quốc gia Đánh giá tác động 10 năm của PFES với sự tham gia của 120 đại biểu đại diện các bên có liên quan để xác nhận lại kết quả của nghiên cứu.

Bảng 3. Tổng hợp số người tham gia họp nhóm thôn/ấp

\begin{tabular}{|c|c|c|c|c|c|}
\hline & Thôn/Ấp & Có DVMTR & Không có DVMTR & Nam & Nũ̃ \\
\hline \multicolumn{6}{|c|}{ Phỏng vấn sâu hộ gia đình } \\
\hline \multirow[t]{2}{*}{ Cặp 1} & Ấp A, xã Đắc Lua, huyện Tân Phú, tỉnh Đồng Nai & $x$ & & 9 & 11 \\
\hline & $\begin{array}{l}\text { Thôn B, xã Đăng Hà, huyện Bù Đăng, tỉnh Bình } \\
\text { Phước }\end{array}$ & & $x$ & 9 & 8 \\
\hline \multirow[t]{2}{*}{ Cặp 2} & $\begin{array}{l}\text { Thôn C, xã Gia Viễn, huyện Cát Tiên, tỉnh Lâm } \\
\text { Đồng }\end{array}$ & $x$ & & 8 & 9 \\
\hline & Ấp D, xã Tà Lài, huyện Tân Phú, tỉnh Đồng Nai & & $\mathrm{x}$ & 7 & 9 \\
\hline \multirow[t]{2}{*}{ Cặp 3} & $\begin{array}{l}\text { Thôn E, xã Tiên Hoàng, huyện Cát Tiên, tỉnh Lâm } \\
\text { Đồng }\end{array}$ & $x$ & & 9 & 10 \\
\hline & Ấp F, xã Đắc Lua, huyện Tân Phú, tỉnh Đồng Nai & & $x$ & 9 & 13 \\
\hline \multirow[t]{2}{*}{ Cặp 4} & $\begin{array}{l}\text { Thôn G, xã Phước Cát 2, huyện Cát Tiên, tỉnh Lâm } \\
\text { Đồng }\end{array}$ & $\mathrm{x}$ & & 8 & 10 \\
\hline & $\begin{array}{l}\text { Thôn H, xã Phước Sơn, huyện Bù Đăng, tỉnh Bình } \\
\text { Phước }\end{array}$ & & $x$ & 11 & 9 \\
\hline Tổng & & & & 70 & 79 \\
\hline
\end{tabular}

* Theo yêu cầu của dự án để đảm bảo đạo đức nghiên cứu, danh tính của nhóm phỏng vấn, tên thật của các bản nghiên cứu sẽ được ẩn danh. 
Bảng 4. Thông tin về phỏng vấn sâu hộ gia đình

\begin{tabular}{|c|c|c|c|c|}
\hline Tên thôn & Có DVMTR & $\begin{array}{l}\text { Không } \\
\text { DVMTR }\end{array}$ & $\begin{array}{l}\text { Tổng số hộ } \\
\text { phỏng vấn }\end{array}$ & $\begin{array}{l}\text { Tổng số hộ } \\
\text { trong toàn thôn }\end{array}$ \\
\hline Ấp A, xã Đắc Lua, huyện Tân Phú, tỉnh Đồng Nai & $x$ & & 30 & 219 \\
\hline $\begin{array}{l}\text { Thôn B, xã Đăng Hà, huyện Bù Đăng, tỉnh Bình } \\
\text { Phước }\end{array}$ & & $\mathrm{X}$ & 30 & 189 \\
\hline $\begin{array}{l}\text { Thôn C, xã Gia Viễn, huyện Cát Tiên, tỉnh Lâm } \\
\text { Đồng }\end{array}$ & $\mathrm{X}$ & & 30 & 178 \\
\hline Ấp D, xã Tà Lài, huyện Tân Phú, tỉnh Đồng Nai & & $\mathrm{X}$ & 30 & 393 \\
\hline $\begin{array}{l}\text { Thôn } E \text {, xã Tiên Hoàng, huyện Cát Tiên, tỉnh Lâm } \\
\text { Đồng }\end{array}$ & $\mathrm{X}$ & & 30 & 189 \\
\hline Ấp F, xã Đắc Lua, huyện Tân Phú, tỉnh Đồng Nai & & $x$ & 30 & 303 \\
\hline $\begin{array}{l}\text { Thôn G, xã Phước Cát 2, huyện Cát Tiên, tỉnh Lâm } \\
\text { Đồng }\end{array}$ & $X$ & & 33 & 35 \\
\hline $\begin{array}{l}\text { Thôn H, xã Phước Sơn, huyện Bù Đăng, tỉnh Bình } \\
\text { Phước }\end{array}$ & & $x$ & 31 & 302 \\
\hline
\end{tabular}

\subsection{Hạn chế của nghiên cứu}

Nghiên cứu này đã giải quyết phân nào lỗ hổng kiến thức được đề cập và đưa ra các bằng chứng khoa học hiện có để chứng minh tác động thực sự của PFES đối với cải thiện sinh kế của người dân tại Vườn Quốc Gia Cát Tiên. Tuy nhiên, nghiên cứu và báo cáo này còn một số hạn chế và hi vọng các nghiên cứu tiếp theo có thể xây dựng dựa trên cả kết quả và hạn chế của nghiên cứu này để tiếp tục hoàn thiện quá trình đánh giá.

Thư nhất, sự thiếu hụt trong tài liệu và số liệu hiện có liên quan đến PFES đã gây nhiều khó khăn trong quá trình đánh giá tác động của PFES. Khung phân tích và phương pháp đánh giá được áp dụng trong nghiên cứu này nhằm để chứng minh tác động của PFES trước và sau khi có PFES, ở nơi có và không có $\mathrm{PFES}$. Tuy nhiên, các số liệu trước khi có PFES tại Cát Tiên không được thu thập và lưu trữ dẫn đến nhiều khó khăn trong việc xác định tính bổ sung của PFES kể từ khi thực hiện. Kết quả phỏng vấn với các cơ quan nhà nước và VQG Cát Tiên cho thấy không có một số liệu nào trước khi có PFES được thu thập và lưu trữ tại Vườn. Ngoài ra, số liệu đã bị thất lạc nên VQG chỉ có số liệu đây đủ và lưu trữ tại hệ thống từ năm 2010 trở lại nay. Để giải quyết thiếu hụt này, nhóm nghiên cứu đã rà soát các tài liệu thứ cấp khác như báo cáo kinh tế, xã hội của xã, huyện và tỉnh. Tuy nhiên, số liệu chỉ giải quyết được phân nào các câu hỏi và thường không thống nhất về cách thu thập số liệu nên gây ra nhiêu thách thức trong quá trình đánh giá. Hiện nay trên toàn quốc mới chỉ có 45 tỉnh thành có $\mathrm{PFES}$ và còn nhiều tỉnh đang chuẩn bị thực hiện. Với các tỉnh chưa thực hiện, tiến hành nghiên cứu đánh giá đường cơ sở trước khi thực hiện PFES và đánh giá lại sau khi có PFES sẽ giúp Việt Nam xác định chính xác hơn hiệu quả của PFES.

Thư hai, quá trình chọn mẫu chuẩn quyết định tới sự chính xác của kết quả nghiên cứu. Việc chọn cặp thôn ở nơi có và không có $\mathrm{PFES}$ có điều kiện hoàn toàn giống nhau, tuy là điều kiện lí tưởng để thiết kế trong nghiên cứu, nhưng trong thực tế rất hiếm khi có hai thôn giống nhau tuyệt đối do vậy nhóm nghiên cứu chỉ có thể chọn tương quan hai thôn gần giống nhau. Các nhà khoa học trong tương lai khi xây dựng các nghiên cứu đánh giá PFES có thể chọn các địa bàn khác với các cặp có nhiêu điểm tương đông hơn để khẳng định độ chính xác của tác động. Ngoài ra, với hạn chế về nguôn lực tài chính và con người, nghiên cứu này chỉ có thể được tiến hành với 4 cặp thôn có $\mathrm{PFES}$ và không có $\mathrm{PFES}$ đại diện. Việc bổ sung các nghiên cứu trong tương lai với một số lượng cặp thôn lớn hơn cũng sẽ giúp đánh giá chính xác hơn.

Thư $b a$, nghiên cứu này chủ yếu tập trung vào thu thập và phân tích các số liệu thu thập từ nghiên cứu tài liệu thứ cấp, phỏng vấn nhóm, phỏng vấn hộ gia đình. Do không có điều kiện và kinh phí, nghiên cứu không thể tiếp cận và thu thập các số liệu viễn thám và số liệu số để so sánh sự thay đổi sử dụng đất và tỉ lệ che phủ rừng, diện tích rừng 
bị mất trước và sau khi có PFES. Ngoài ra, việc bản đồ số hóa tại khu vực nghiên cứu cũng hạn chế bởi các cơ quan nhà nước và VQG Cát Tiên cũng không có đủ nguôn lực tài chính và con người để làm việc này. Việc tiến hành bổ sung các nghiên cứu phân tích số liệu viễn thám là cân thiết trong tương lai bởi điều này vừa có thể giúp kiểm chửng thực tế trên thực địa tác động của PFES cũng như kết hợp với số liệu định tính thông qua phỏng vấn để đề xuất các hoạt động phù hợp, cụ thể cho từng địa phương trong việc cải thiện quá trình thực hiện PFES. 


\section{Khái quát về VQG Cát Tiên và thực trạng chi trả DVMTR tại VQG Cát Tiên}

Vườn quốc gia Cát Tiên là một khu bảo tôn thiên nhiên nằm trên địa bàn 5 huyện thuộc 3 tỉnh: Tân Phú, Vĩnh Cửu (Đồng Nai), Cát Tiên, Bảo Lâm (Lâm Đông) và Bù Đăng (Bình Phước). VQG Cát Tiên được thành lập theo quyết định số 01/CT ngày 13 tháng 1 năm 1992 của Thủ tướng chính phủ Cộng hòa Xã hội Chủ nghĩa Việt Nam trên cơ sở kết nối khu rừng cấm Nam Cát Tiên (được thành lập theo quyết định số 360/ TTg, ngày 7 tháng 7 năm 1978 của Thủ tướng chính phủ) và khu bảo tôn thiên nhiên Tây Cát Tiên (được thành lập theo quyết định số 194/CT, ngày 9 tháng 8 năm 1986 của Chủ tịch Hội đông Bộ trưởng).

Vườn quốc gia Cát Tiên nằm ở khu vực có toạ độ từ $11^{\circ} 20^{\prime} 50^{\prime \prime}$ tới $11^{\circ} 50^{\prime} 20^{\prime \prime}$ vĩ bắc, và từ $107^{\circ} 09^{\prime} 05^{\prime \prime}$ tới $107^{\circ} 35^{\prime} 20^{\prime \prime}$ kinh đông. VQG Cát Tiên là một trong những chủ rừng lớn nhất thuộc VNFOREST - Bộ NN\&PTNT, có diện tích 82.597,4ha nằm trên địa bàn của 3 tỉnh: Đồng Nai, Lâm Đồng và Bình Phước; có một hệ sinh thái điển hình cho khu vực Đông Nam Bộ với hệ động thực vật phong phú và đa dạng; được UNESCO công nhận là Khu dự trũ sinh quyển thế giới thứ 411 vào năm 2001.

Thực hiện Nghị định số 99/2010/NĐ-CP, ngày 24/9/2010 của Chính phủ, hằng năm Vườn quốc gia Cát Tiên thực hiện công tác khoán bảo vệ rừng theo chương trình chi trả DVMTR 03 tỉnh Đồng Nai, Lâm Đồng và Bình Phước. Vườn xây dựng hồ sơ thuyết minh, bản cam kết bảo vệ rừng với cộng đồng dân cư nhận khoán BVR trình Sở NN\&PTNT tỉnh Đồng Nai, Lâm Đồng và Bình Phước đông thời, triển khai ký hợp đông với các tổ nhận khoán để thực hiện công tác bảo vệ rừng.

Về đối tượng nhận khoán: thực hiện việc quản lý họ tên hộ nhận khoán bằng chứng minh nhân dân, ngoài ra phối hợp chặt chẽ với UBND các xã tổ chức họp thôn bản thường xuyên rà soát danh sách các hộ đủ tiêu chí theo quy định, ưu tiên các hộ đông bào dân tộc, hộ nghèo, hộ có sức khỏe, nhiệt tình... để tham gia vào tổ cộng đồng nhận khoán.

Dòng chảy ngân sách của chi trả DVMTR được thể hiện thông qua Hình 2.

Theo số liệu báo cáo diễn biến rừng hàng năm của VGQ Cát Tiên thì diện tích rừng của VQG Cát Tiên phân chia thành 2 giai đoạn và tương đối ổn định qua các năm trong mỗi giai đoạn. Từ năm 2008 đến 2016 diện tích rừng tăng từ 71,187 ha đến 72,606 ha và từ 2017 đến 2019 , diện tích rừng tăng nhẹ lên hơn 80,000ha. Cán bộ VQG Cát Tiên cũng cho biết, diện tích tăng lên khoảng 10 nghìn ha như vậy là do thời điểm 2016 sang 2017, VGQ tiếp nhận thêm khoảng 10 nghìn hecta diện tích rừng trước đây thuộc quyền quản lý của công ty Lâm nghiệp La Ngà.

So sánh với tổng diện tích VQG Cát Tiên quản lý thì diện tích cung ứng DVMTR từ năm 2010 đến năm 2013 chỉ chiếm 38\% nhưng từ 2014 trở đi do DVMTR bắt đầu triển khai thêm ở 2 tỉnh là Đông Nai và Bình Phước vì vậy mà diện tích cung ứng DVMTR chiếm đến hơn $80 \%$ tổng diện tích rừng mà VQG Cát Tiên quản lý (Hình 3).

Theo số liệu từ VQG Cát Tiên cung cấp thì diện tích cung ứng dịch vụ môi trường rừng có sự biến động hàng năm nhưng xu thế chung là tăng từ 2010 cho đến 2019 , từ 27,008ha lên đến 78,477 ha. Tuy nhiên diện tích cung ứng dịch vụ môi trường tăng cũng là phần đáng kể do diện tích rừng do VQG quản lí tăng, chứ không phải do sự gia tăng tự nhiên của rừng. Diện tích cung ứng chi trả DVMTR tại VQG Cát Tiên trải rộng trên 3 tỉnh Lâm Đồng, Đồng Nai và Bình Phước; từ năm 2010 đến 2013 thì diện tích cung ứng chỉ thuộc diện tích của tỉnh Lâm Đông và thời 

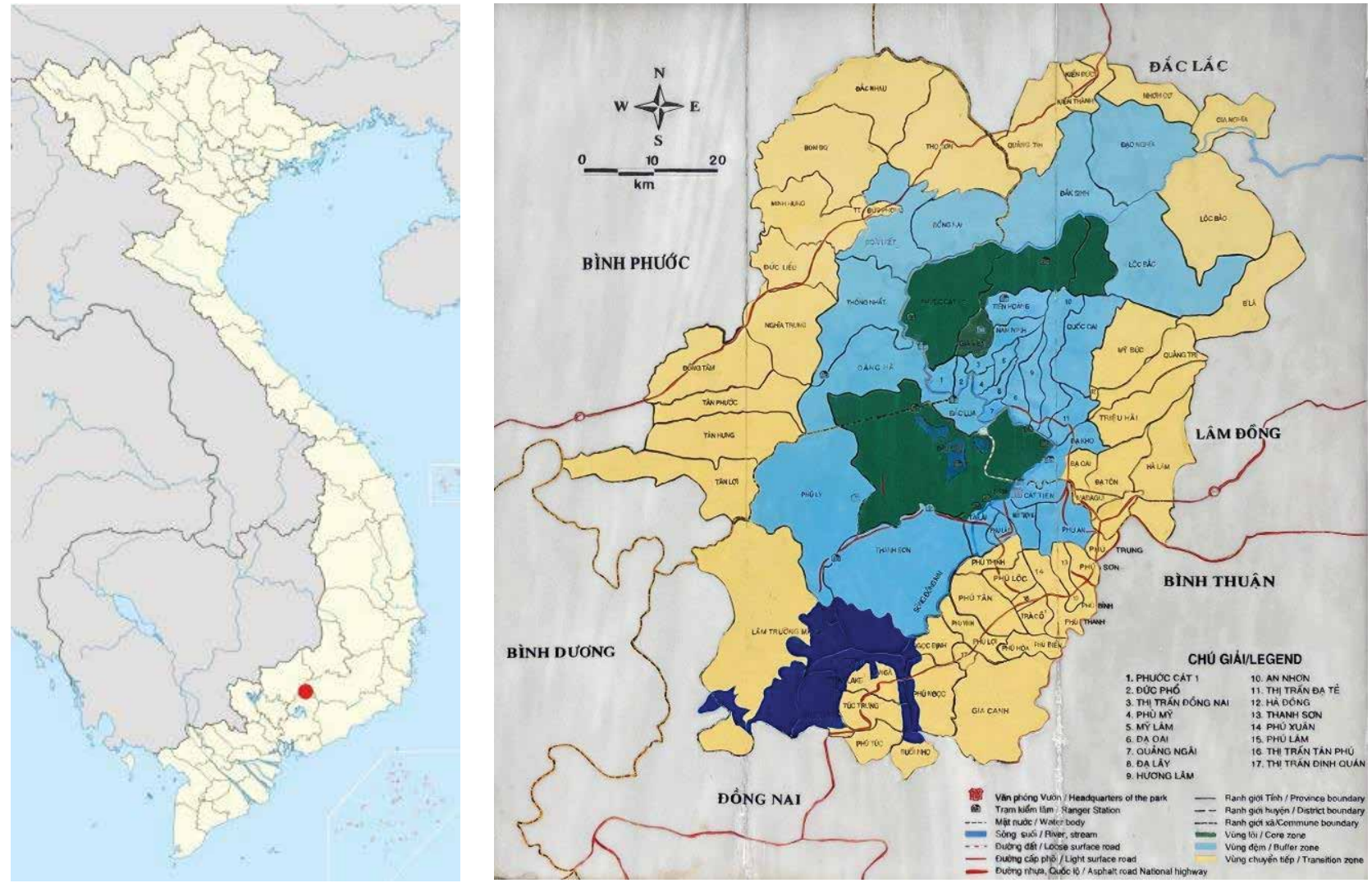

Hình 1. Vị trí VQG Cát Tiên trên bản đồ Việt Nam

Nguồn: nhóm nghiên cứu tự tổng hợp

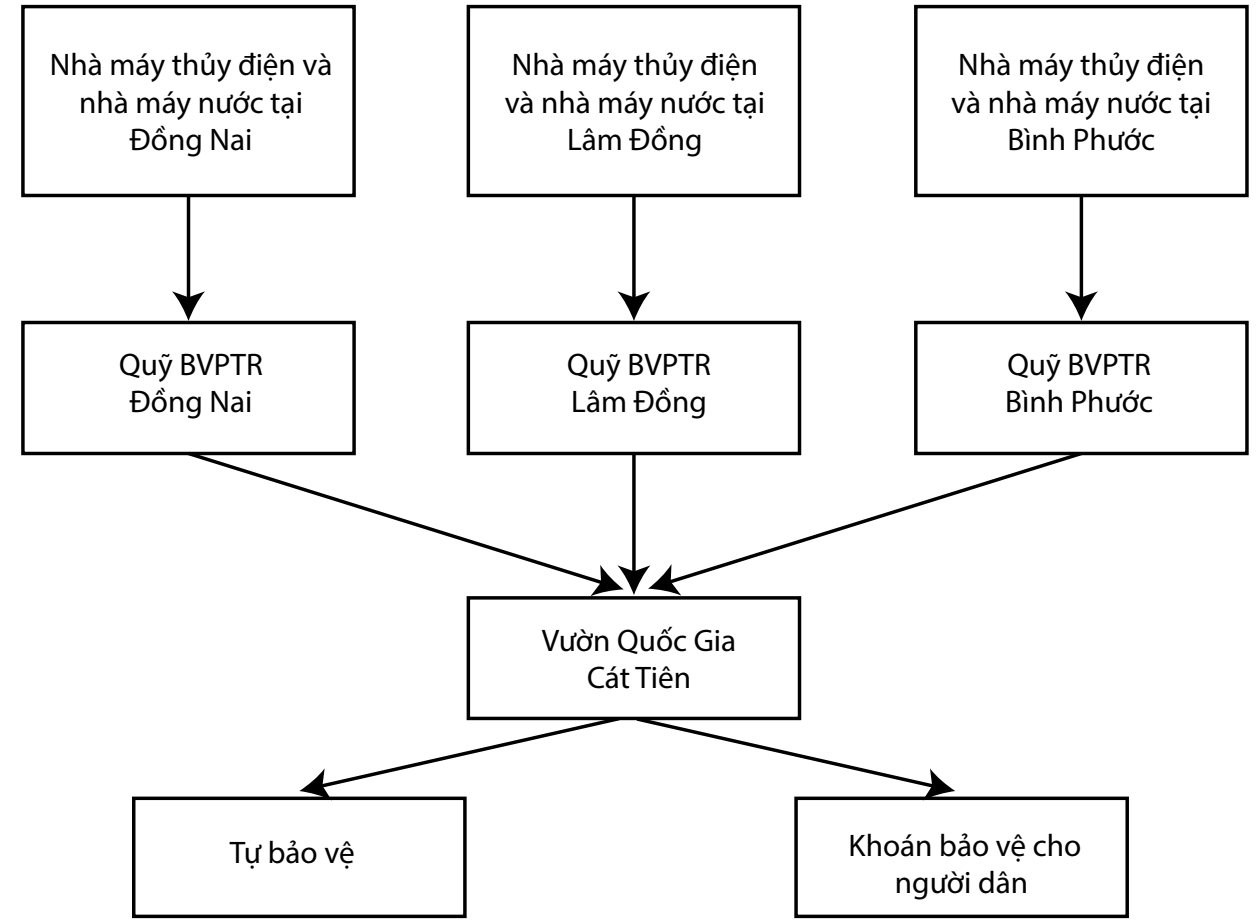

Hình 2. Dòng chảy tài chính của tiền DVMTR tại VQG Cát Tiên

Nguồn: nhóm nghiên cứu tự tổng hợp 


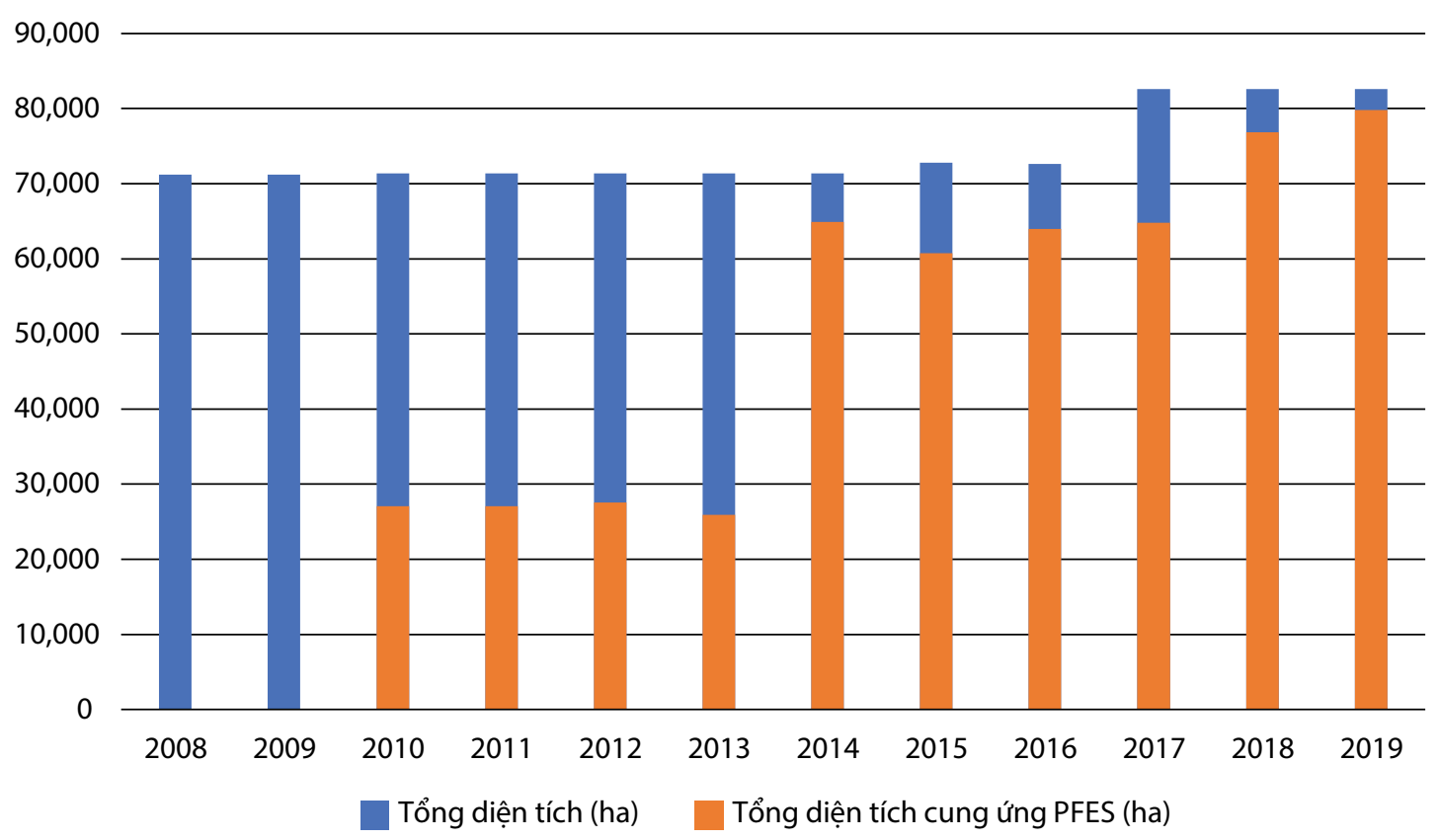

Hình 3. Tổng diện tích cung ứng DVMTR tại VQG Cát Tiên

Nguồn: Số liệu VQG Cát Tiên cung cấp

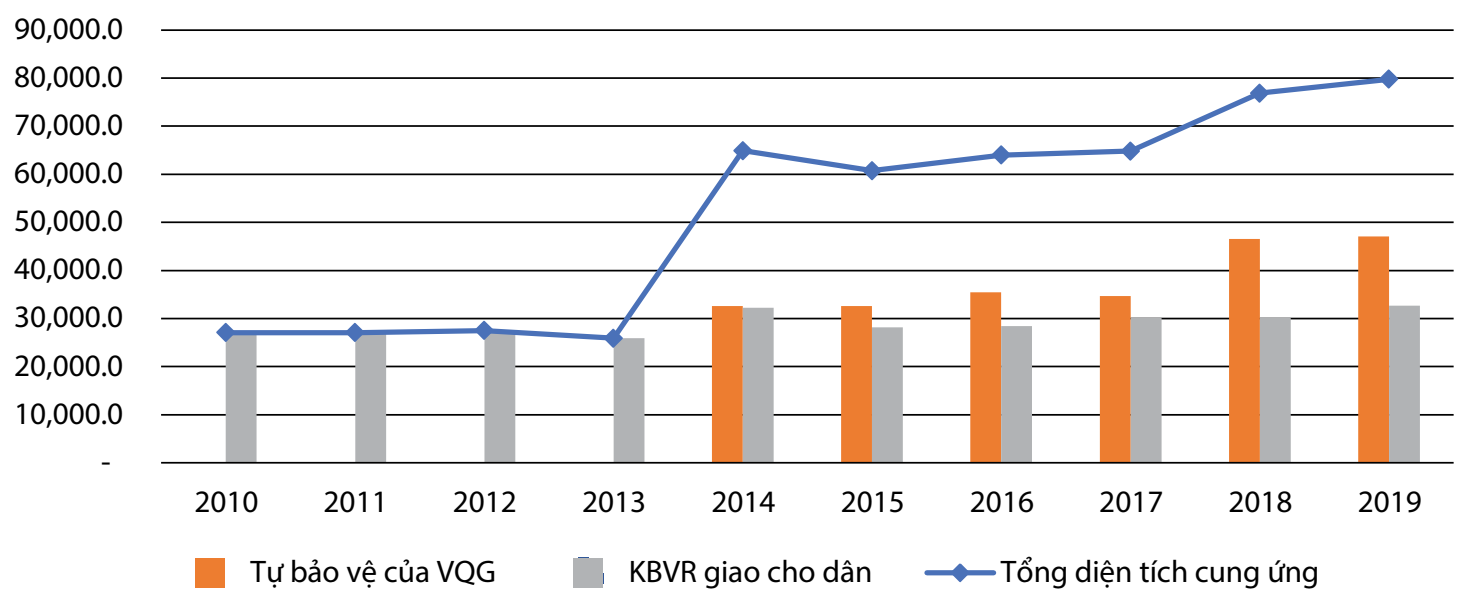

Hình 4. Diện tích tự bảo vệ và diện tích giao khoán cho người dân tại VQG Cát Tiên

Nguồn: Số liệu VQG Cát Tiên cung cấp

điểm đó thì diện tích cung ứng DVMTR giao khoán hết cho người dân bảo vệ. Đến 2014 trở đi, chương trình DVMTR tiến hành triển khai tại 2 tỉnh còn lại, diện tích cung ứng tăng lên hơn gấp đôi so với thời điểm trước. Phần diện tích này cũng được phân ra cho cả người dân bảo vệ và VQG tự bảo vệ (Hình 4).

Từ 2010 đến 2013, mới chỉ có diện tích thuộc Lâm Đồng được giao khoán BVR nên 100\% diện tích nhận khoán thuộc Lâm Đồng. Trong giai đoạn từ 2014 đến 2019, diện tích cung ứng
DVMTR tại VQG Cát Tiên trải rộng trên địa bàn 3 tỉnh trong đó, Đồng Nai chiếm diện tích lớn nhất từ $54 \%$ đến $61 \%$ tổng diện tích; sau đó Lâm Đồng dao động trong khoảng 34\% đến $40 \%$ tiếp đến là Bình Phước chỉ chiếm 5-7\% tổng diện tích cung ứng DVMTR tại Vườn (Hình 5)

Cụ thể hơn, tỷ lệ phân bổ diện tích rừng cho người dân khoán bảo vệ rừng và vườn quốc gia tự bảo vệ lại khác nhau ở 3 tỉnh. Tại Đông Nai, diện tích VQG tự bảo vệ chiếm hơn $80 \%$ còn lại là giao khoán cho người dân. Tại Lâm Đồng thì 


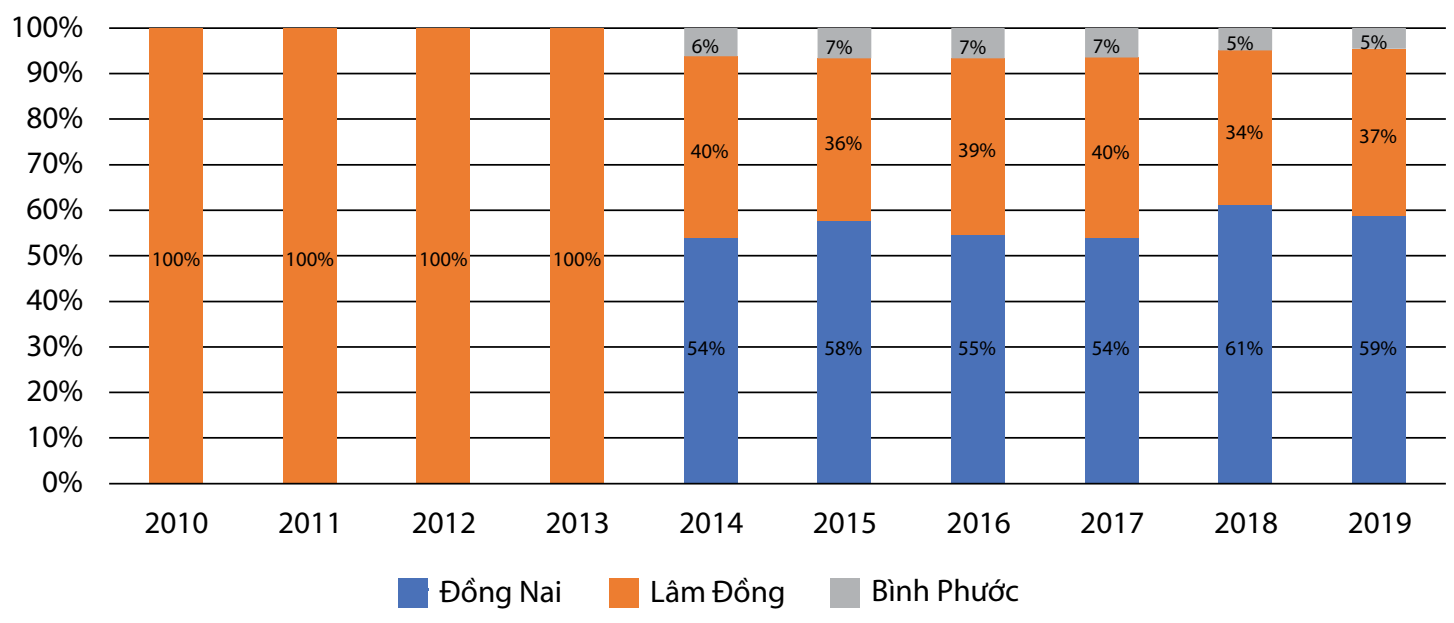

Hình 5. Phân bổ diện tích cung ứng tại VQG Cát Tiên

Nguồn: Số liệu VQG Cát Tiên cung cấp
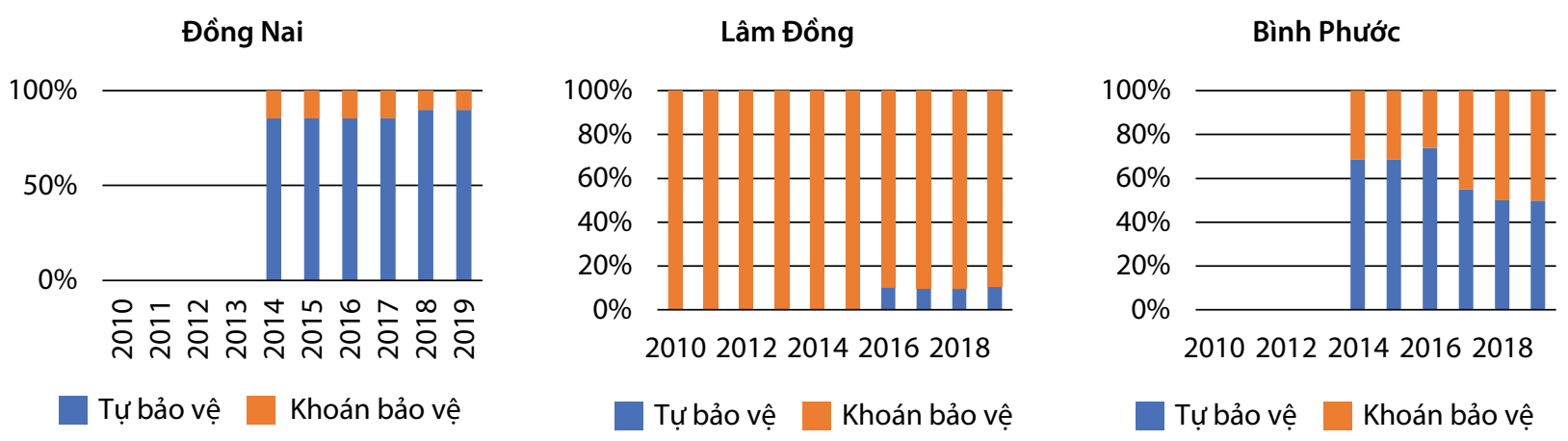

Hình 6. Tỷ lệ tự bảo vệ và khoán bảo vệ tại VQG Cát Tiên

Nguôn: Số liệu VQG Cát Tiên cung cấp

phần lớn diện tích cung ứng DVMTR được giao cho người dân khoán bảo vệ. Từ năm 2016 cho tới nay, một phân diện tích được phân bổ cho Vườn tự bảo vệ. Còn ở tỉnh Bình Phước thì phân lớn từ 2014 đến năm 2016, diện tích cung ứng DVMTR được Vườn tự bảo vệ cao hơn diện tích khoán cho người dân nhưng từ 2017 đến 2019, diện tích cung ứng DVMTR trên địa bàn tỉnh này được phân bổ đông đều giữa Vườn và người dân (Hình 6). 


\section{Tác động xã hội của PFES}

Chỉ số vê đóng góp của DVMTR cho cộng đồng được VNFF đánh giá thông qua 2 tiêu chí là: Số tiền và số lượng các công trình, trang thiết bị và hoạt động phúc lợi cộng đông được xây dựng từ tiền DVMTR và tỷ lệ số tiền DVMTR trong tổng số chi phí xây dựng nông thôn mới. Tuy nhiên, kết quả khảo sát cho thấy tại VQG Cát Tiên, dù VQG kí khoán bảo vệ rừng các cộng đồng thuộc VQG Cát Tiên bằng tiền của DVMTR nhưng số tiền lại được chi trả đến từng hộ gia đình theo ngày công họ đi tuần tra bảo vệ rừng chứ không có quỹ chung để chi tiêu cho các công trình công cộng. Theo thông tin từ các cuộc thảo luận nhóm (5/8 thôn nghiên cứu) thì những công trình cộng đông trong thôn được xây dựng và tu sửa là từ nguôn ngân sách của chương trình khác (như chương trình khoán bảo vệ rừng theo Quyết định $24^{2}$ hỗ trợ mỗi cộng đông 40 triệu hay những chương trình hỗ trợ khác của nhà nước). Chính bởi vậy, tác động của DVMTR đối với các công trình phúc lợi hay đối với cộng đồng không áp dụng được trong bối cảnh của Cát Tiên. Do vậy, trong phân báo cáo này chúng tôi chỉ tập trung phân tích tác động của PFES đối với hộ gia đình.

\subsection{Số hộ dân tộc thiểu số được nhận tiền chi trả DVMTR}

Theo phỏng vấn với cán bộ địa phương và cán bộ của VQG Cát Tiên, tại các thôn nghiên cứu chưa hề có một thống kê chính xác nào về số hộ dân tộc thiểu số nhận được tiền khoán bảo vệ rừng trước khi có $P F E S$ và sau khi có PFES DVMTR tại cả những thôn có và không có PFES. Tuy nhiên, đối với những thôn không có DVMTR, từ trước đến nay không có hộ gia dình dân tộc thiểu số nào nhận được tiền hỗ trợ từ khoán bảo vệ rừng. Trong khi đó, ở những thôn có DVMTR, vào năm 2019 tuy số lượng hộ dân tộc thiểu số nhận được tiền DVMTR là không cao nhưng lại chiểm tỉ trọng cao trong tổng số các hộ là người dân tộc tại các thôn tham gia DVMTR (ví dụ: 66.7\% ở Ấp A, xã Đắc Lua, huyện Tân Phú, tỉnh Đông Nai và $92.1 \%$ tại thôn $\mathrm{G}$, xã Phước Cát 2 , huyện Cát Tiên, tỉnh Lâm Đồng (Bảng 5). Trong 4 thôn được chọn làm nghiên cứu, không có thôn nào có số hộ dân tham gia chương trình là người dân tộc thiểu số dưới $50 \%$. Cá biệt tại thôn $\mathrm{G}$, xã Phước Cát 2 chỉ có 3 trên 38 hộ tham gia là người Kinh, cho thấy rằng thôn này là một ví dụ tiêu biểu của chính sách ưu tiên đưa những hộ dân tộc thiểu số vào chương trình chi trả DVMTR.

\subsection{Số hộ nghèo được nhận tiền chi trả DVMT'R và số hộ thoát nghèo}

Đối với những thôn không có DVMTR, từ trước đến nay không có hộ nghèo nào nhận được tiền hỗ trợ từ khoán bảo vệ rừng do toàn bộ diện tích rừng được quản lí trực tiếp bởi Vườn Quốc Gia Cát Tiên. Tại các thôn có PFES, số lượng hộ nghèo được tham gia DVMTR trên tổng số hộ nghèo trong thôn chiếm tỷ lệ từ $45 \%$ và cao nhất là $88 \%$ (Bảng 6). Điều này cho thấy ở địa bàn có PFES, người nghèo có thêm thu nhập từ bảo vệ
2 Quyết định 24 Về chính sách đầu tư phát triển rừng đặc dụng giai đoạn 2011 - 2020. Đối với chương trình này, ngân sách nhà nước hỗ trợ đầu tư cho cộng đồng dân cư thôn bản vùng đệm để đồng quản lý rừng đặc dụng; mức hỗ trợ mỗi thôn bản là 40 triệu đông/thôn, bản/năm. Khoản kinh phí này được chi cho các nội dung: Đầu tư nâng cao năng lực phát triển sản xuất (khuyến nông, khuyến lâm, giống cây, giống con, thiết bị chế biến nông lâm sản quy mô nhỏ); hỗ trợ vật liệu xây dựng cho thôn bản (đối với các công trình công cộng của cộng đông như nước sạch, điện chiếu sáng, thông tin liên lạc, đường giao thông thôn bản, nhà văn hoá...) 
Bảng 5. Tỷ lệ số hộ dân tộc thiểu số nhận được tiền DVMTR 2019

\begin{tabular}{|c|c|c|c|}
\hline Tên thôn được triển khai DVMTR & $\begin{array}{l}\text { Tổng số hộ dân tộc nhận } \\
\text { được tiền DVMTR }\end{array}$ & $\begin{array}{l}\text { Tổng số hộ dân tộc } \\
\text { trong toàn thôn }\end{array}$ & Tỷ lệ \\
\hline $\begin{array}{l}\text { Ấp A, xã Đắc Lua, huyện Tân Phú, tỉnh } \\
\text { Đồng Nai }\end{array}$ & 4 & 6 & $66.7 \%$ \\
\hline $\begin{array}{l}\text { Thôn C, xã Gia Viễn, huyện Cát Tiên, tỉnh } \\
\text { Lâm Đồng }\end{array}$ & 7 & 14 & $50 \%$ \\
\hline $\begin{array}{l}\text { Thôn E, xã Tiên Hoàng, huyện Cát Tiên, } \\
\text { tỉnh Lâm Đồng }\end{array}$ & 8 & 15 & $53 \%$ \\
\hline $\begin{array}{l}\text { Thôn G, xã Phước Cát 2, huyện Cát Tiên, } \\
\text { tỉnh Lâm Đồng }\end{array}$ & 35 & 38 & $92.1 \%$ \\
\hline
\end{tabular}

Nguồn: Số liệu VQG Cát Tiên cung cấp

Bảng 6. Tỷ lệ hộ nghèo nhận được DVMTR trong các thôn ấp

\begin{tabular}{|c|c|c|c|}
\hline Tên thôn được triển khai DVMTR & $\begin{array}{l}\text { Tổng số hộ nghèo nhận } \\
\text { được tiền DVMTR }\end{array}$ & $\begin{array}{l}\text { Tổng số hộ nghèo trong } \\
\text { toàn thôn }\end{array}$ & Tỷ lệ \\
\hline $\begin{array}{l}\text { Ấp A, xã Đắc Lua, huyện Tân Phú, tỉnh } \\
\text { Đồng Nai }\end{array}$ & 10 & 22 & $45 \%$ \\
\hline $\begin{array}{l}\text { Thôn C, xã Gia Viễn, huyện Cát Tiên, tỉnh } \\
\text { Lâm Đồng }\end{array}$ & 6 & 12 & $50 \%$ \\
\hline $\begin{array}{l}\text { Thôn E, xã Tiên Hoàng, huyện Cát Tiên, } \\
\text { tỉnh Lâm Đồng }\end{array}$ & 10 & 15 & $67 \%$ \\
\hline $\begin{array}{l}\text { Thôn G, xã Phước Cát 2, huyện Cát Tiên, } \\
\text { tỉnh Lâm Đồng }\end{array}$ & 22 & 25 & $88 \%$ \\
\hline
\end{tabular}

Nguồn: Số liệu VQG Cát Tiên cung cấp

rừng trong khi các hộ nghèo ở các địa bàn không có PFES không có điều kiện để nâng cao sinh kế này.

Trong tổng số hộ nghèo tham gia DVMTR tại các thôn nghiên cứu, 22\% không có nguồn thu nhập bằng tiền mặt nào khác ngoài tiên khoán bảo vệ rừng và $81.4 \%$ số hộ nghèo này khi có thêm tiền khoán bảo vệ rừng thì đã thoát nghèo (chiếm $81.4 \%$ tổng số hộ nghèo tham gia DVMTR).

\subsection{Sự tham gia của người dân vào chươnig trình bảo vệ và phát triển rừng}

Tại cả thôn có và không có PFES, người dân đều được tham gia vào các chương trình phát triển kinh tế xã hội do nhà nước tiến hành như chương trình hỗ trợ cây giống, con giống; chương trình vay vốn cho con đi học, chương trình vay vốn ngân hàng chính sách, chương trình hỗ trợ xây nhà vệ sinh, hỗ trợ điện nước, cấp thẻ bảo hiểm y tế hay những chương trình đào tào dạy nghề. Tuy nhiên, các thôn không có PFES, người dân cũng không được tham gia hay hưởng lợi từ bất cứ chương trình bảo vệ rừng nào. Trong khi đó, người dân ở các thôn có PFES, ngoài việc hưởng lợi từ các chương trình nhà nước khác còn được hưởng lợi thêm từ chính sách PFES.

Đối với thôn có DVMTR, thì tỷ lệ hộ dân được nhận tiền từ DVMTR là $72 \%$. Mặc dù PFES đã đem lại nhiều lợi ích cho người nghèo và người dân tộc thiểu số, một số người Kinh tại Phước Cát 2 cho rằng chương trình $\mathrm{PFES}$ hiện nay chưa công bằng bởi người Kinh không thể tham gia vào chương trình $\mathrm{PFES}$. Theo kết quả phỏng vấn với các bên liên quan, do theo quy định của nhà nước chỉ giao đất rừng và lợi ích liên quan 
đến rừng ưu tiên cho người dân tộc bản địa nên người Kinh không được phân đất đai hay đất rừng, do vậy không thể tham gia hưởng lợi từ PFES. Tuy nhiên, những hộ dân người Kinh cảm thấy mình bị phân biệt đối xử và đồng thời cho rằng khi rừng trong thôn cháy hay có sự xâm lấn của người ngoài, họ vẫn được điều động đi để bảo vệ rừng nhưng lại không được hưởng lợi từ chính sách này.
Theo kết quả phỏng vấn 123 hộ tại 4 thôn tham gia DVMTR có $70 \%$ tham gia vào việc triển khai DVMTR tại thôn/ấp của họ. Khi tham gia DVMTR, người dân được tập huấn nhiều kĩ năng mới như đo đạc sinh khối ( $9 \%$ người phỏng vấn) và làm rõ ranh giới đất rừng (36\% người phỏng vấn). Những kĩ năng này đóng vai trò quan trọng trong việc giúp người dân giám sát diện tích và số tiên nhận được từ DVMTR. 


\section{Tác động kinh tế của PFES}

\subsection{Diện tích giao khoán bảo vệ rừng cho người dân}

Cán bộ VQG Cát Tiên cho biết trước khi có PFES đã có nhiêu chương trình bảo vệ và phát triển rừng được tiến hành trên địa bàn bao gồm chương trình $661^{3}, 30 \mathrm{~A}^{4}, 304^{5}$. Các chương trình đã giao khoán bảo vệ rừng cho người dân, đến khi hết giai đoạn thực hiện các chương trình đó vào năm 2010 thì chương trình DVMTR bắt đầu được chọn để thay thế và trở thành nguôn tài chính chủ đạo cho khoán bảo vệ rừng tại VQG Cát Tiên.

Khi tiến hành PFES trên địa bàn, diện tích rừng được giao khoán cho người dân được tăng lên đáng kể, nhờ đó thu nhập của người dân cũng tăng lên. Dựa theo Hình 7 và Hình 8 , trước khi có $\mathrm{PFES}$, diện tích rừng được giao khoán bảo vệ rừng tại VQG Cát Tiên chỉ là 8,851 hecta chiếm tỉ trọng $12 \%$ tổng diện tích rừng của VQG Cát Tiên. Tuy nhiên, sau khi có $\mathrm{PFES}$, diện tích rừng được giao cho cộng đông và hộ gia đình quản lí gấp 3 tới 3.64 lần so với trước khi có PFES. Diện tích do người dân quản lí bảo vệ rừng thông qua khoán bảo vệ sau khi có PFES cũng chiếm tỉ trọng cao hơn trước khi có PFES, từ 37\%-39\% tổng diện rừng của VQG quản lí. Điêu này tạo nhiều cơ hội cho người dân và cộng đông hưởng lợi kinh tế từ các chương trình bảo vệ phát triên rừng, bao gồm PFES.

3 Dự án trồng mới 5 triệu ha rừng

4 Chương trình hỗ trợ giảm nghèo nhanh và bền vững đối với 61 huyện nghèo

5 Chương trình thí điểm giao rừng, khoán bảo vệ rừng cho hộ gia đình và cộng đồng trong buôn, làng là đông bào dân tộc thiểu số tại chỗ ở các tỉnh tây nguyên

\subsection{Số HGD nhận khoán BVR/Số HGD được nhận tiền chi trả DVMTR}

Theo cán bộ VQG Cát Tiên cho biết, những cộng đồng đã tham gia khoán BVR từ những chương trình trước đây sẽ tiếp tục được tham gia vào chương trình chi trả DVMTR. Những thay đổi rất nhỏ về số lượng cộng đông tham gia nhận khoán (Hình 9) chủ yếu là do việc nhập và tách các cộng đông theo chủ trương của nhà nước. Tuy số lượng cộng đông nhận khoán không thay đổi trước và sau DVMTR nhưng số lượng hộ dân tham gia khoán bảo vệ rừng từ khi có DVMTR giảm hơn hẳn so với trước khi có DVMTR (Bảng 7).

Theo phỏng vấn tiến hành với cán bộ VQG Cát Tiên, trước PFES, VQG giao khoán cho các cộng đông và tất cả các hộ dân đều được tham gia vào cộng đồng. Tuy nhiên sau đó VQG Cát Tiên cho rằng hình thức không hiệu quả do không có người chuyên trách. Từ năm 2011, VQG Cát Tiên hướng dẫn và hỗ trợ các cộng đông bầu chọn và thống nhất một số hộ gia đình nhất định để tham gia vào $P F E S$ sử dụng các tiêu chí như sức khỏe, hộ nghèo, sống gần rừng, gia đình chính sách...

Bảng 8 cho thấy số hộ khảo sát nhận được tiền PFES khác nhau giữa các thôn và dao động từ 7\%-100\%. Đối với các thôn có $100 \%$ hộ tham gia PFES, mọi hộ phỏng vấn đều đánh giá cao vai trò của PFES. Đối với các thôn chỉ có một phân nhỏ hộ dân được tham gia PFES $(<10 \%)$, các bên phỏng vấn cho rằng lợi ích từ PFES chỉ tập trung một số nhóm người được lựa chọn, và đôi khi lợi ích từ PFES không được chia sẻ rộng rãi.

Khác với thôn có DVMTR, từ trước đến này cả 4 thôn không tham gia DVMTR không có hộ gia đình nào nhận được khoán bảo vệ rừng. Ngay cả trong trường hợp của thôn $\mathrm{B}$, Đăng Hà, tuy nhận 


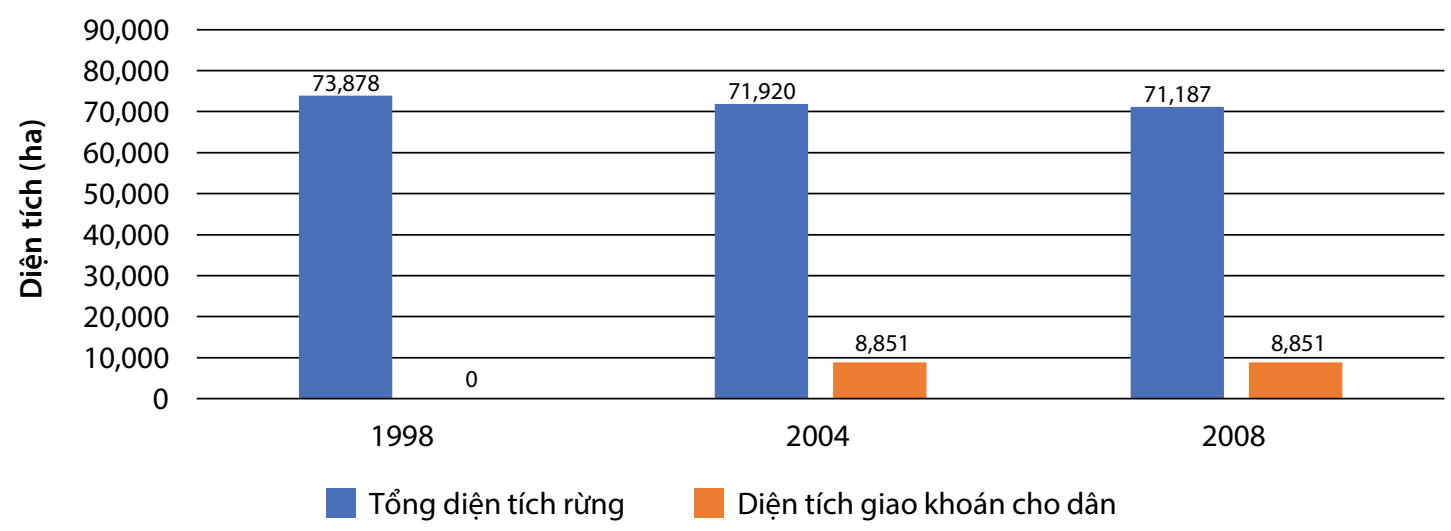

Hình 7. Diện tích giao khoán cho người dân trước khi PFES

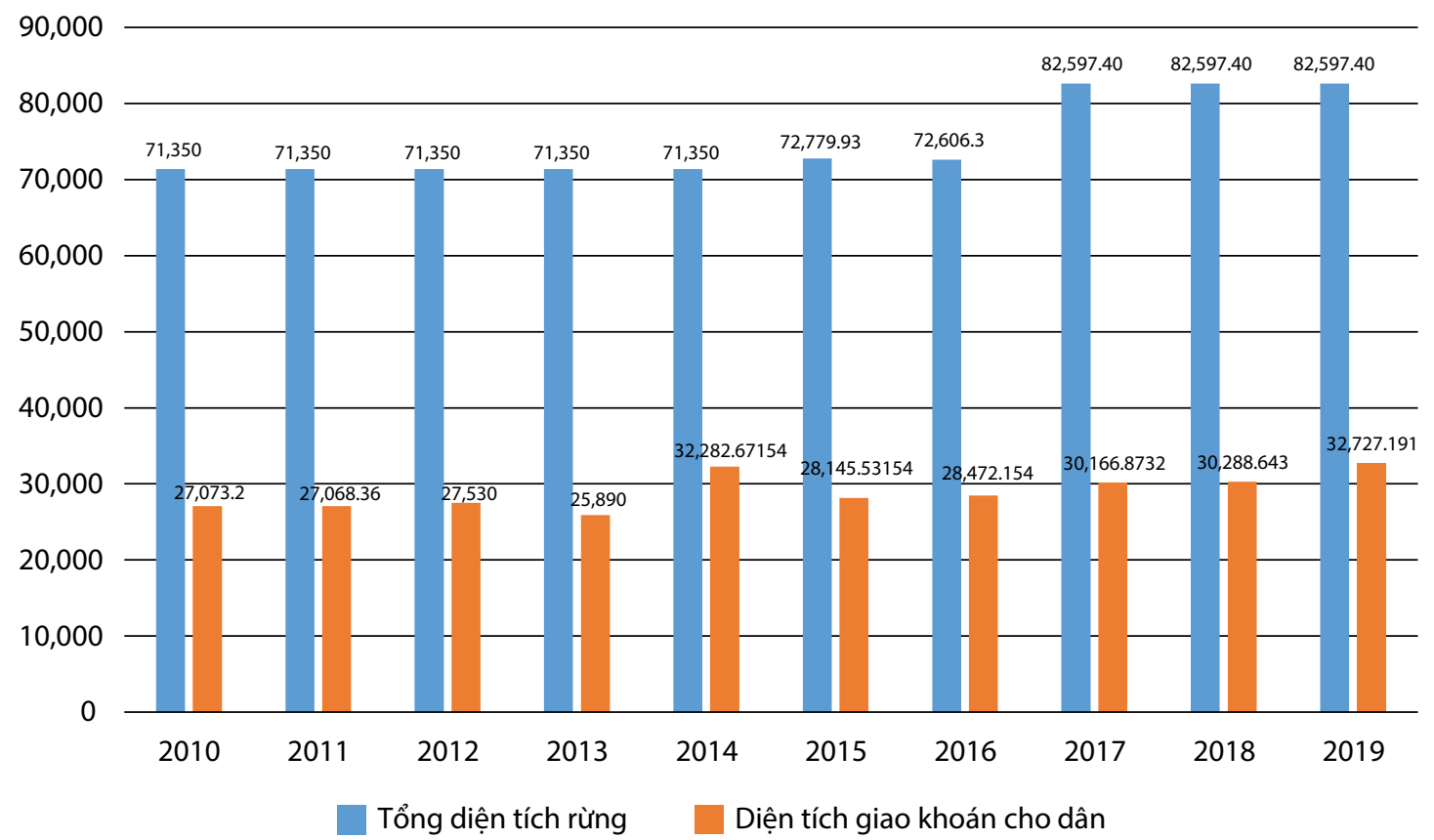

Hình 8. Diện tích giao khoán bảo vệ rừng cho cộng đồng và hộ dân từ khi có PFES

Bảng 7. Số cộng đồng và số hộ tham gia DVMTR phân theo từng tỉnh

\begin{tabular}{lcccccc}
\hline Năm & \multicolumn{2}{c}{ Đồng Nai } & \multicolumn{2}{c}{ Lâm Đồng } & \multicolumn{2}{c}{ Bình Phước } \\
\cline { 2 - 7 } & Số C甲 & Số hộ & Số C甲 & Số hộ & Số C甲 & Số hộ \\
\hline 2010 & & 23 & 2031 & & \\
\hline 2011 & & 22 & 688 & & \\
\hline 2012 & & 22 & 691 & & \\
\hline 2013 & 12 & 239 & 23 & 927 & & \\
\hline 2014 & 12 & 194 & 27 & 585 & 6 & 160 \\
\hline 2015 & 12 & 180 & 27 & 1,023 & 6 & 104 \\
\hline 2016 & 12 & 221 & 28 & 955 & 6 & 62 \\
\hline 2017 & 12 & 220 & 29 & 963 & 6 & 61 \\
\hline 2018 & 11 & 190 & 30 & 952 & 6 & 68 \\
\hline 2019 & & 1244 & & 9,738 & & 50 \\
\hline & & & & & \\
\hline
\end{tabular}

Nguồn: Số liệu VQG Cát Tiên cung cấp 


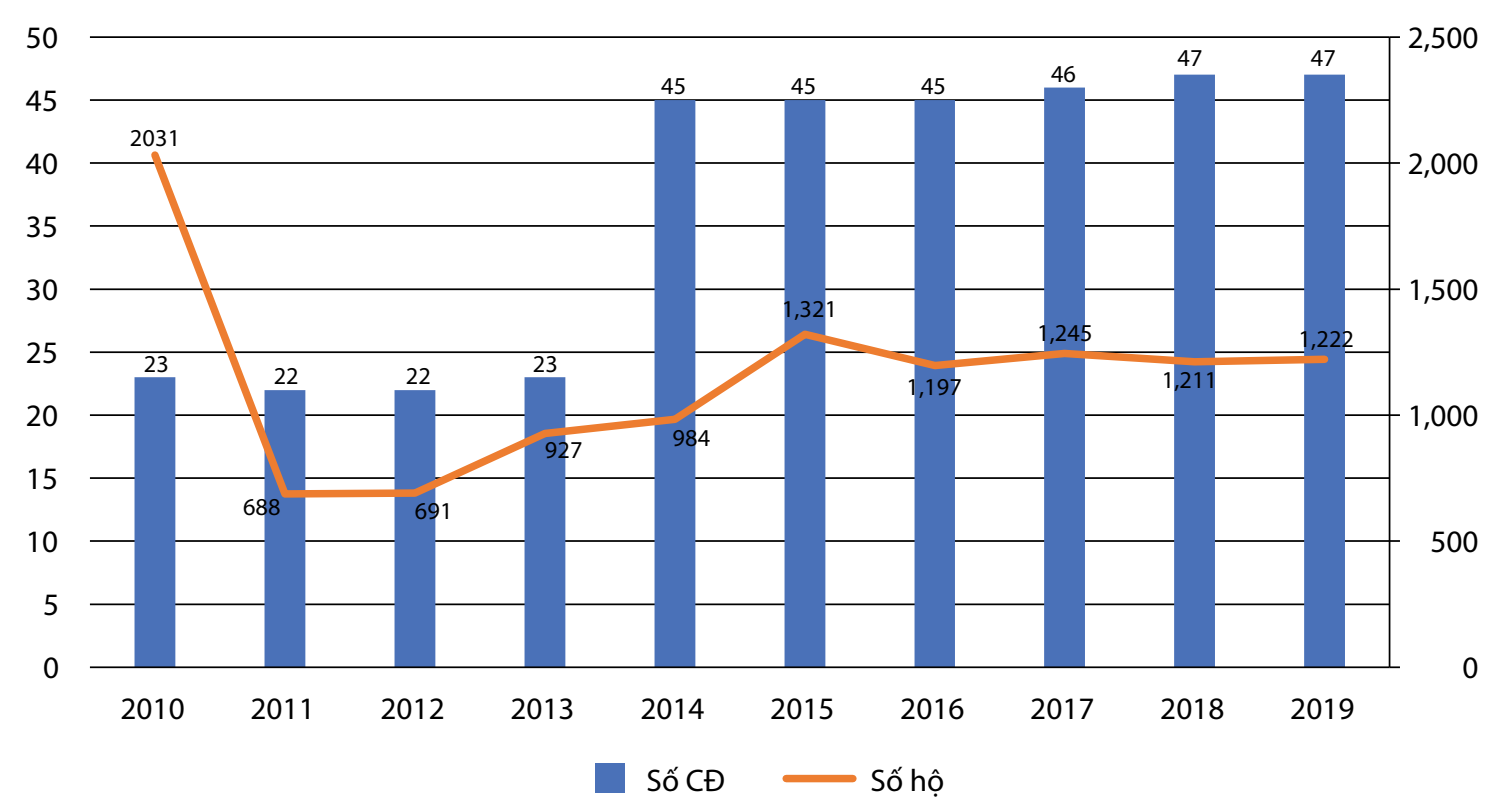

Hình 9. Số cộng đồng và số hộ nhận khoán bảo vệ rừng tại VQG Cát Tiên

Nguồn: Số liệu VQG Cát Tiên cung cấp

Bảng 8. Tỷ lệ số hộ nhận tiền DVMTR

Tên thôn được triển khai DVMTR Tổng số hộ nhận được tiền DVMTR

\section{Tổng số hộ trong Tỷ lệ} toàn thôn

43

219

$20 \%$

Ấp A, xã Đắc Lua, huyện Tân Phú, tỉnh Đồng Nai

\begin{tabular}{lrrr}
\hline Thôn C, xã Gia Viễn, huyện Cát Tiên, tỉnh Lâm Đồng & 27 & 178 & $15 \%$ \\
\hline Thôn E, xã Tiên Hoàng, huyện Cát Tiên, tỉnh Lâm Đồng & 14 & 189 & $7 \%$ \\
\hline Thôn G, xã Phước Cát 2, huyện Cát Tiên, tỉnh Lâm Đồng & 35 & 35 & $100 \%$ \\
\hline Tổng & 119 & 621 & $19 \%$ \\
\hline
\end{tabular}

Nguồn: Số liệu VQG Cát Tiên cung cấp

được hỗ trợ từ chương trình 24 thì số tiền hỗ trợ chỉ dành cho các hoạt động phát triển cộng đông chứ không được dùng để tổ chức khoán bảo vệ rừng. Theo phỏng vấn với cán bộ của VQG Cát Tiên, mỗi thôn ấp tại VQG Cát Tiên nhận được hỗ trợ 24 này sẽ ký cam kết hàng năm với Vườn và chất lượng kết quả thực hiện cam kết bảo vệ rừng trong năm là căn cứ để Vườn quốc gia Cát Tiên xem xét nghiệm thu kết quả đâu tư của năm đó. Quyết định hỗ trợ phát triển cho thôn ấp năm tiếp theo cũng lấy cơ sở từ đây chứ không cần phải đi tuân tra bảo vệ rừng như chương trình DVMTR. Nếu trong năm, có người dân trong ấp vi phạm các điều cam kết trong văn bản cam kết này hoặc ấp không thực hiện đâuu tư đúng kế hoạch hay dự toán được duyệt, thì tùy theo tính chất, mức độ mà Vườn quốc gia Cát Tiên sẽ bàn bạc, thống nhất với UBND xã thu hồi kinh phí đã tạm ứng trong năm và sẽ không hỗ trợ cho năm tiếp theo.

\subsection{Số tiền nhận được trung bình trên một ngày công tuần tra bảo vệ rừng được chi trả DVMTR}

Ở những thôn không có DVMTR, không có bất cứ hộ gia đình nào nhận được tiền công đi tuần tra bảo vệ rừng. Trong khi đó ở thôn có DVMTR, các hộ dân tham gia chương trình chi trả DVMTR theo hình thức nhận khoán bảo vệ rừng dưới dạng rừng cộng đồng. Mỗi cộng đồng sẽ có một người là đại diện gọi là Tổ trưởng của cộng đồng đó, sẽ là người đứng ra ký kết hợp 
Bảng 9. Mức chi trả tiền khoán bảo vệ rừng trước và sau PFES

\begin{tabular}{|c|c|c|c|}
\hline & Trước PFES & \multicolumn{2}{|r|}{ Sau PFES } \\
\hline & Không có PFES & Có PFES & Không có PFES \\
\hline $\begin{array}{l}\text { Hình } \\
\text { thức chi } \\
\text { trả }\end{array}$ & $\begin{array}{l}\text { Không chia theo ngày công mà chỉ tính theo } \\
\text { số tiên trên } 1 \text { ha bảo vệ rừng của cả cộng } \\
\text { đông và sau đó chia đều trong cộng đồng }\end{array}$ & $\begin{array}{l}\text { Tính toán theo ngày } \\
\text { công họ đi tuần tra } \\
\text { bảo vệ }\end{array}$ & $\begin{array}{l}\text { Chỉ nhận được tiền hỗ trợ qua } \\
\text { hỗ trợ cộng đồng }\end{array}$ \\
\hline $\begin{array}{l}\text { Mức chi } \\
\text { trảa }\end{array}$ & $50-100,000 \mathrm{VND} / \mathrm{ha}$ & $\begin{array}{l}\text { 115,198 VND/ngày } \\
\text { 493,000 VND/ngày }\end{array}$ & 40 triệu VND/năm \\
\hline
\end{tabular}

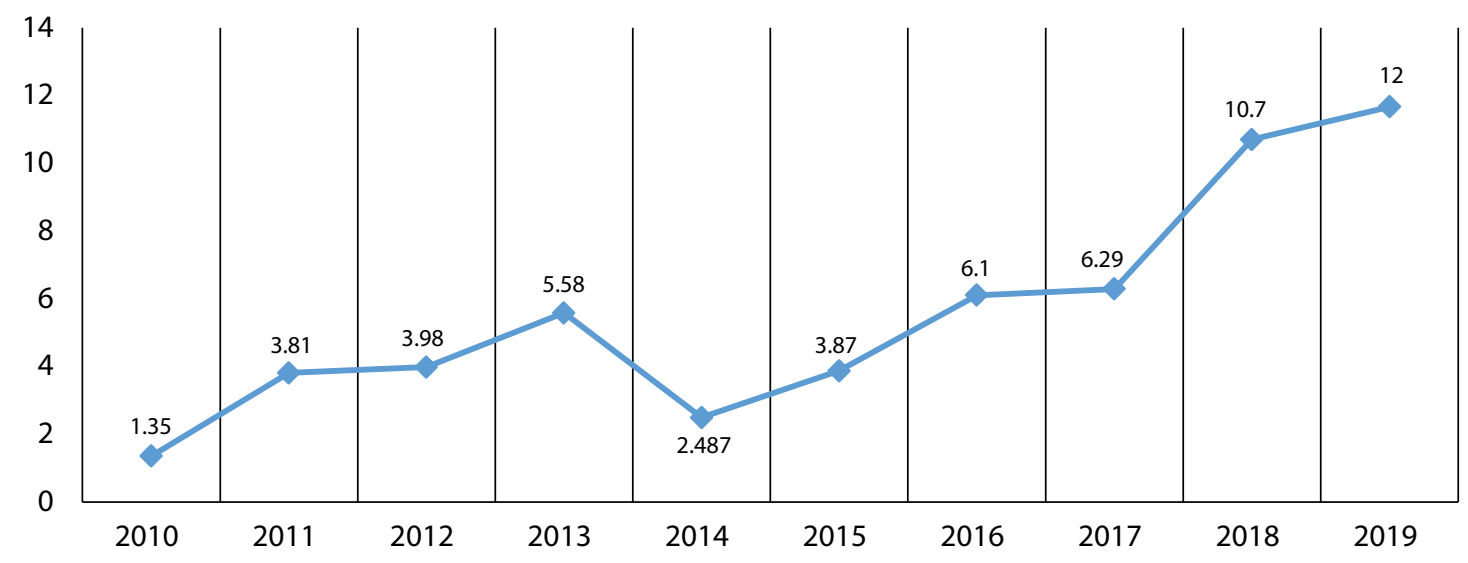

Hình 10. Thu nhập từ PFES qua các năm (Đơn vị: triệu VND)

Nguồn: tác giả tự tổng hợp

đồng khoán BVR với VQG Cát Tiên. Một cộng đông sẽ có danh sách bao gồm các hộ gia đình đủ điều kiện tham gia chi trả DVMTR, một cộng đồng có thể là các hộ trong cùng một thôn hoặc hơn 1 thôn. Tổ trưởng tổ nhận khoán là người có trách nhiệm xây dựng kế hoạch tuần tra bảo vệ rừng; phân công lực lượng tuần tra trên diện tích nhận khoán theo định kỳ hàng tuần, tháng, quý và năm và mỗi ngày công đi tuần tra của từng hộ sẽ được ghi chép lại đây đủ để làm căn cứ trả tiền DVMTR cho từng hộ gia đình trong thôn.

Trước DVMTR, các chương trình như 661,30a và 304 cũng là các chương trình khoán bảo vệ rừng nhưng lại không chia theo ngày công mà chỉ tính theo số tiền trên 1 ha bảo vệ rừng của cả cộng đông và sau đó chia đều trong cộng đồng. Từ 2010 trở về trước, Chương trình 661 chi trả cho các hộ tham gia BVR từ 50-100,000/ha. Sau khi có DVMTR, từ năm 2010 đến 2016, tiền khoán bảo vệ rừng được chia đều cho các hộ dân trong cộng đồng. Nhưng đến giai đoạn từ năm 2017 cho đến 2019, thì tiền khoán bảo vệ rừng của mỗi hộ dân được tính toán theo ngày công họ đi tuân tra bảo vệ rừng, những thôn nào số ngày công các hộ đi bằng nhau vẫn chọn hình thức chia đều (ví dụ: năm 2017, tiên công cho 1 ngày đi tuần tra BVR tại thôn $\mathrm{C}$, Gia Viễn là 493,000/ngày; năm 2019, tiên công cho 1 ngày đi tuân tra BVR tại ấp $\mathrm{A}$, Đắc Lua là 115,198/ngày (Bảng 9).

Hình 10 cũng cho thấy số tiên trung bình mỗi hộ nhận được từ PFES qua các năm có xu thế tăng lên.

Từ năm 2010 đến 2019, đơn giá chi trả DVMTR tại Đồng Nai, Lâm Đồng và Bình Phước được thể hiện trong Hình 9, đơn giá có xu hướng chung là tăng dần qua các năm nhưng chi tiết từng năm cũng có sự biến động phụ thuộc vào việc sử dụng dịch vụ của các bên mua dịch vụ môi trường rừng vào những năm đó (Hình 11).

Do đơn giá chi trả DVMTR của Đông Nai rất thấp nếu so với Bình Phước và Lâm Đồng (Hình 11), nên VGQ Cát Tiên đã quyết định dùng tiên khoán bảo vệ rừng của Quyết định 24 để 


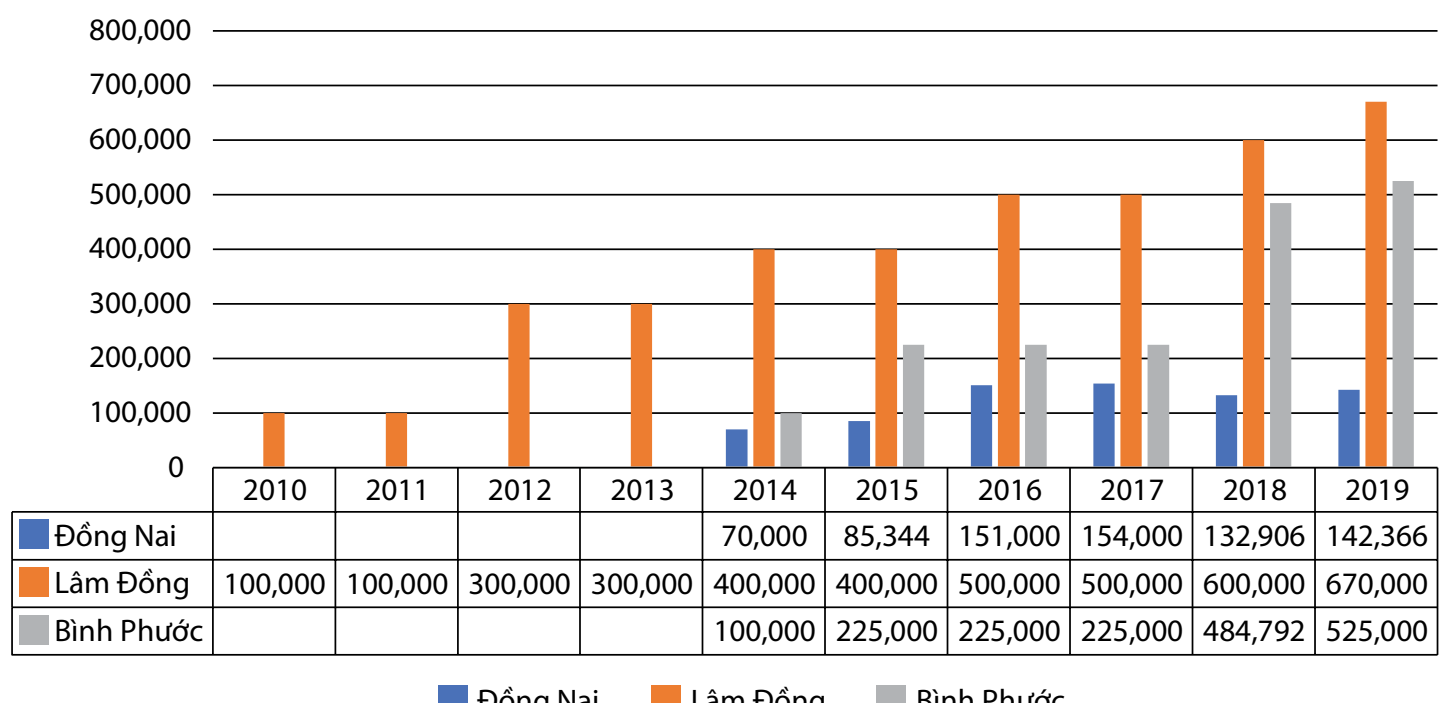

Hình 11. Đơn giá chi trả DVMTR

Nguồn: Số liệu VQG Cát Tiên cung cấp

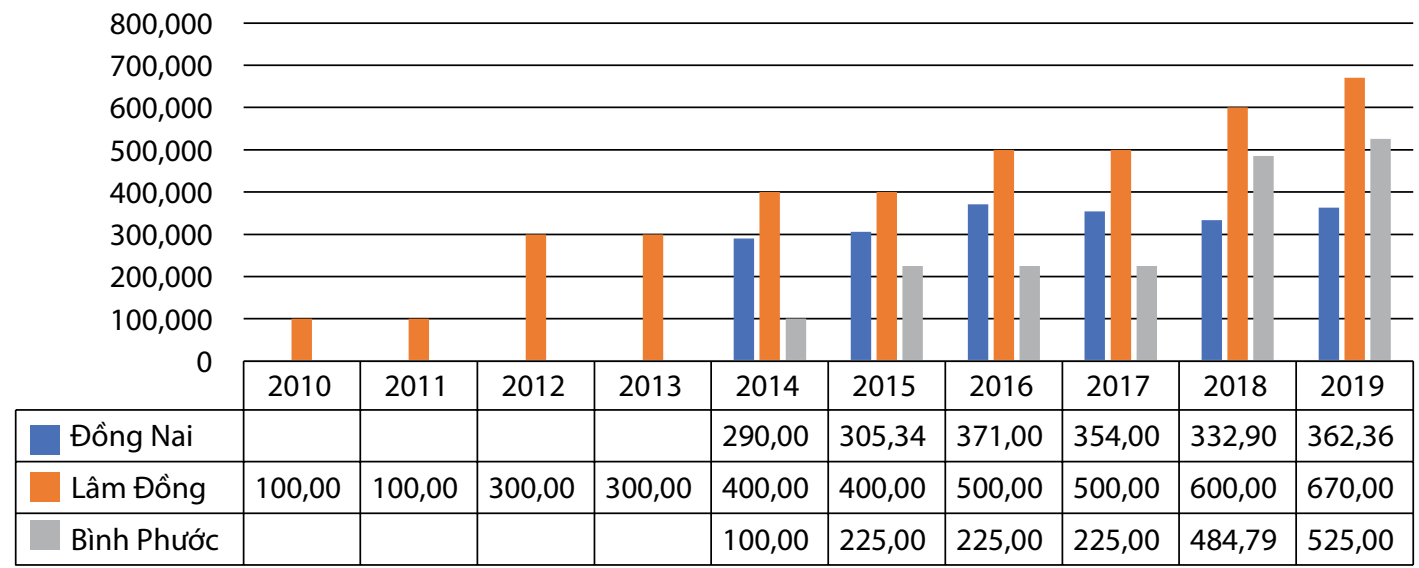

Hình 12. Đơn giá chi trả DVMTR và quyết định 24 (chỉ áp dụng cho Đồng Nai)

Nguồn: Số liệu VQG Cát Tiên cung cấp

bổ sung thêm vào nguôn PFES hiện đang chi trả cho người dân tại Đông Nai. Trong thực tế, VQG đã cân đối ngân sách để cộng thêm vào đơn giá 200,000 - 220,000 đông/ha cho diện tích DVMTR mà người dân tại Đông Nai nhận khoán bảo vệ rừng (Hình 12). Tuy nhiên, sau khi kiểm toán nhà nước không đông tình với việc cùng một diện tích rừng mà có 2 nguồn chi trả nên VQG Cát Tiên đã ban hành quy định mới là số tiền được nhận khoán tại Đồng Nai không vượt quá 300,000 đồng/ha. Việc tăng đơn giá lên cho tỉnh Đồng Nai giúp đơn giá chi trả của tỉnh Đồng Nai gần tiếp cận với Bình Phước.

\subsection{Tỉ trọng thu nhập từ PFES trong tổng thu nhập của hộ gia đình}

Đối với các hộ khá giả, PFES chiếm tỷ trọng từ 20\% (Ấp A- Đăc Lua) tới 50\% trong tổng thu nhập của hộ (Thôn G, Xã Phước Cát). Hình 13 cũng có thấy, PFES đang đóng góp từ $8 \%$ cho tới $100 \%$ trong tổng thu nhập của hộ gia đình tại 4 thôn nghiên cứu tại thời điểm năm 2019. Tính trung bình, PFES đóng góp từ $16 \%$ cho tới $74 \%$ trong tổng thu nhập của hộ gia đình tại các thôn có $P F E S$ vào năm 2019. 


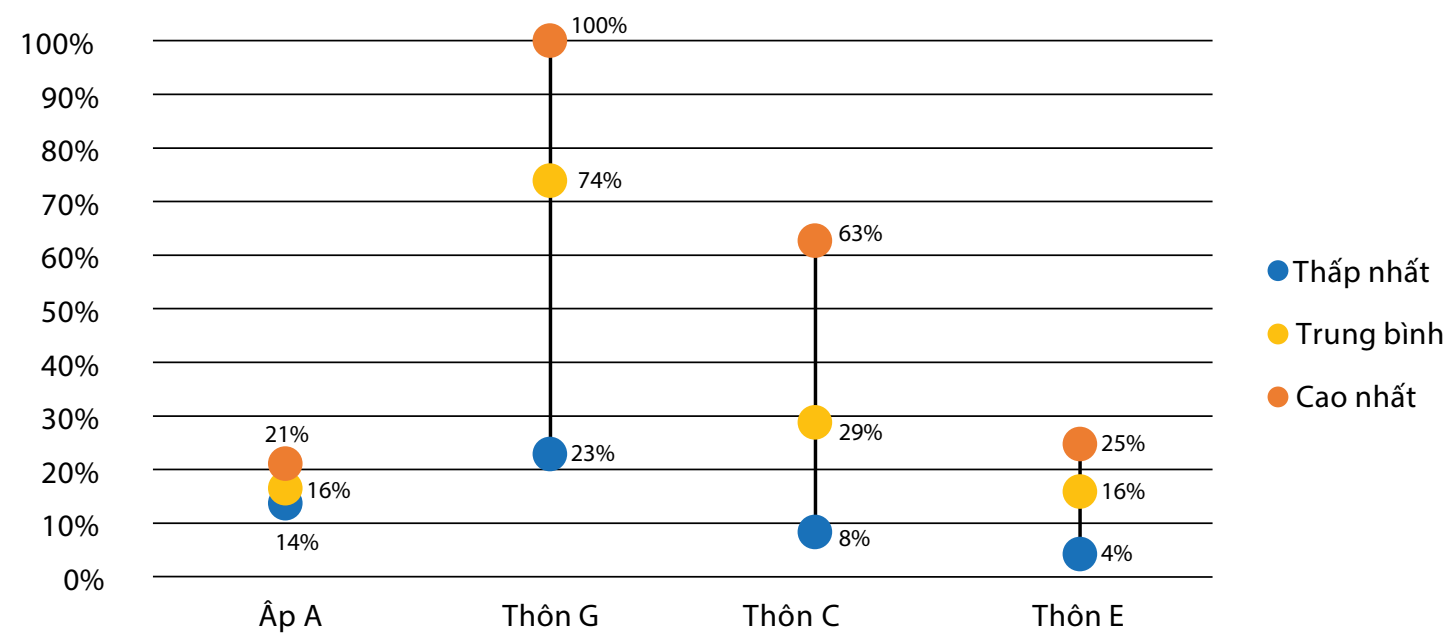

Hình 13. Đóng góp của PFES vào tổng thu nhập năm 2019

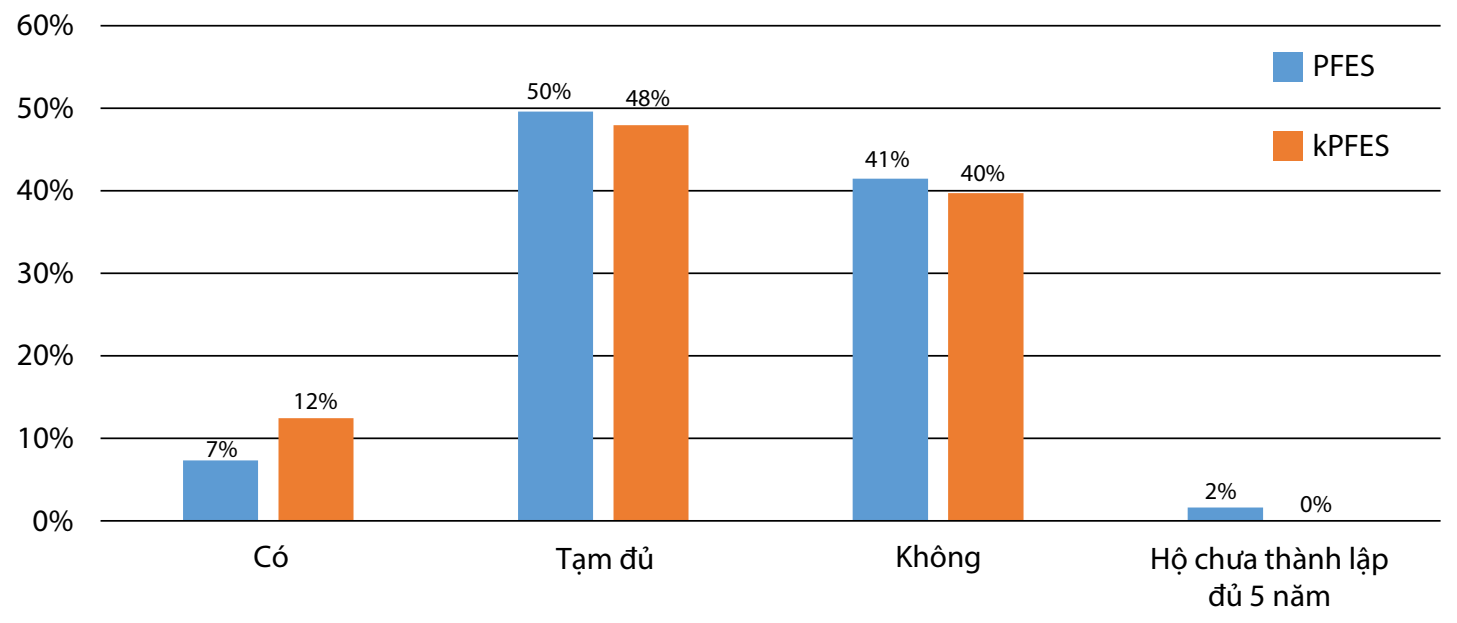

Hình 14. Nhận thức về vấn đề đảm bảo thu nhập cho cuộc sống trong 10 năm qua

Người dân tại thôn $\mathrm{B}$, Tiên Hoàng cho biết từ năm 2015-2019 người dân không có việc làm do mất mùa điều, chăn nuôi dịch bệnh, kinh tế xuống mạnh, nợ ngân hàng đời sống bà con khó khăn (Họp nhóm Nam tại thôn B, Tiên Hoàng). Người dân tại thôn $\mathrm{H}$, Phước Sơn cũng đề cập rằng "Năm 2017 đến nay mất mùa đêu, giá mủ cao su thấp làm cho kinh tế người dân trong thôn gặp nhiều khó khăn. Những năm 2010, mỗi ha điều đến cuối mùa có thể hái được 4 tấn, giai đoạn này chỉ được khoảng 200kg" (Họp nhóm Nam tại thôn $\mathrm{H}$, Phước Sơn). Người dân tại buổi họp nhóm nữ ở thôn $\mathrm{G}$, Phước Cát 2 cũng bày tỏ "Khoảng 3 năm gần đây mất mùa điê̂u, sống nhờ vào tiền rừng là chính". Tại Ấp $\mathrm{A}$, Đắc Lua chủ hộ Hoàng Văn $\mathrm{S}$ cũng bày tỏ "điều không thu được do mất mùa liên tục", chủ hộ Vi Văn D cũng cho biết "điều 3 năm mất mùa không thu được đông nào". Anh Điểu K K tại thôn G, Phước Cát 2 cũng chia sẻ "Khoảng 3 năm trở lại đây do mất mùa điêu, lại mất giá nên tôi đã cưa hạ bỏ 01 thửa còn lại chỉ thu khoảng 1,000,000 d/năm". Tại thôn G, Phước Cát 2 từ 2016 trở đi do mất mùa điều nên cuộc sống của người dân gặp nhiều khó khăn vì vậy từ thời điểm đó thôn $\mathrm{G}$ cũng nhận được nhiều chương trình hỗ trợ của nhà nước như hỗ trợ con giống, cây giống, hỗ trợ làm nhà. Tuy nhiên, trong bối cảnh mất mùa, DVMTR đã trở thành nguồn tài chính duy nhất ổn định giúp người dân tồn tại. Hộ Điểu T $\mathrm{H}$ cho biết nhà mình "sống nhờ tiền rừng" hay bác Điểu $\mathrm{T} \mathrm{G}$ cho biết mình "chỉ sống một mình, không làm ăn buôn bán gì nên hỗ trợ thu nhập thế này tốt vì bà già cũng không lao động được". Trước bối cảnh rủi ro này, DVMTR trở thành nguồn thu nhập ổn định duy nhất giúp người dân đảm bảo cuộc sống chi tiêu hàng ngày. 
Qua kết quả phỏng vấn 123 hộ thuộc 4 thôn tham gia DVMTR và 121 hộ thuộc 4 thôn không tham gia DVMTR cho thấy phần lớn thu nhập của các hộ chỉ tạm đủ chi tiêu trong gia đình trong 10 năm qua. Đặc biệt những thôn không có DVMTR thì tỷ lệ những người cho rằng thu nhập của họ trong 10 năm qua đủ chi tiêu trong gia đình cao hơn $5 \%$ so với thôn có triển khai chương trình DVMTR (Hình 14).

Tuy nhiên, trong thực tế nếu chỉ tính các loại hình thu nhập từ rừng trong cơ cấu thu nhập của các hộ dân thì nguôn thu từ lâm nghiệp là không đáng kể. Chỉ khi có thêm thu nhập từ khoán bảo vệ rừng thì nguôn thu từ rừng mới đem tại tác động nhiêu đến thu nhập của họ. Kết quả phân tích từ các cuộc thảo luận nhóm cho thấy mức đóng góp của DVMTR vào nguồn thu nhập của người dân ở các thôn nghiên cứu có DVMTR rất khác nhau. Tại thôn $\mathrm{G}$, xã Phước Cát 2, tiên DVMTR đóng góp rất đáng kể vào nguôn thu nhập của người dân ở đây. Tiền DVMTR mà mỗi hộ nhận được là khoảng 28 triệu/năm. Hộ thuộc vào loại có thu nhập khá ở trong thôn một năm cũng chỉ kiếm được từ 50-70 triệu/ năm. Tiên DVMTR đóng góp đến $50 \%$ vào thu nhập của các hộ khá giả trong thôn và là nguồn thu duy nhất của $17 \%$ hộ trong thôn $\mathrm{G}$, Phước Cát 2 . Tuy nhiên, tiên chi trả DVMTR chỉ đóng góp từ $10 \%$ vào thu nhập của những hộ khá giả và $20-30 \%$ những hộ nghèo của Âp $\mathrm{A}$, Đắc Lua vì mức chi trả ở thôn này chỉ từ $4-5$ triệu/năm trong khi thu nhập của những hộ khá giả tại đây là 40 triệu đông/năm và có những hộ thu nhập lên đến 150 triệu/năm. 


\section{Thảo luận và đề xuất}

VQG Cát Tiên là khu rừng được đánh giá cao về tiềm năng đa dạng sinh học, giữ vững nhiều danh hiệu lớn: Khu dự trữ sinh quyển Thế giới (năm 2001), Khu đất ngập nước - Ramsar (năm 2005), Khu di tích Quốc gia đặc biệt (năm 2012), nên thường xuyên nhận được sự quan tâm của nhiều tổ chức trong và ngoài nước đối với công tác bảo vệ và phát triển nguôn tài nguyên quý giá.

Báo cáo này chỉ ra rằng PFES đã có tác động kinh tế và xã hội tích cực đối với nhiều hộ gia đình tham gia khảo sát này. Với nguồn thu ổn định và tăng đều qua hàng năm, PFES đã giúp xóa đói giảm nghèo, tăng thêm thu nhập và tạo công ăn việc làm cho nhiều hộ gia đình. Mặc dù vậy, việc chia sẻ lợi ích từ PFES, đặc biệt trong bối cảnh chỉ có một phân nhỏ hộ gia đình được thôn lựa chọn tham gia bảo vệ rừng và các chính sách chủ yếu ưu tiên vào người dân tộc thiểu số cũng tạo ra những thách thức trong việc đảm bảo công bằng với tất cả cộng đông dân cư. Ngoài ra, kết quả nghiên cứu đã cho thấy, người dân tham gia vào $\mathrm{PFES}$ đã được hướng dẫn và đào tạo trong việc tuân tra rừng, xác định trữ lượng carbon và đánh giá đa dạng sinh học. Tuy nhiên, cho tới nay mới chỉ có một nhóm nhỏ các hộ dân và hộ gia đình được tiếp cận với những hỗ trợ này.

Như đã trình bày ở trong phân hạn chế của nghiên cứu, vấn đề lưu trũ̃ thông tin phục vụ theo dõi và đánh giá chưa đạt hiệu quả cao, các số liệu thống kê đặt biệt trong giai đoạn trước khi thực hiện chính sách chi trả DVMTR không được lưu trữ đây đủ và thống nhất. Do cách sắp xếp, lưu trũ chưa khoa học, và do việc thay đổi nhân sự thường xuyên dẫn đến không bàn giao lại số liệu nghiêm túc vì vậy gây khó khăn trong việc thu thập lại số liệu cũ và không thể đánh giá được một cách toàn diện tác động của chính sách chi trả DVMTR tại VQG Cát Tiên.
Dựa trên những phân tích ở trên vê PFES tại địa bàn Vườn Quốc Gia Cát Tiên, nhóm nghiên cứu đưa ra những đề xuất sau để đóng góp vào việc cải thiện và hoàn chỉnh chính sách. Những đóng góp này không chỉ dành riêng cho bối cạnh cụ thể ở VQG Cát Tiên mà có thể áp dụng vào việc triển khai PFES ở những nơi khác, tùy theo điêu kiện địa phương.

\subsection{Giải pháp thể chế và chính sách}

Tăng cường thực thi pháp luật. Việc thực thi pháp luật này không thể chỉ phụ thuộc vào cán bộ kiểm lâm mà còn cần sự phối hợp của người dân và cộng đồng địa phương. Hơn nữa, việc thực thi pháp luật đối với lực lượng kiểm lâm cũng đòi hỏi phải có các hồ trợ và cơ chế thu hút nguồn lực cho các hạt kiểm lâm đồng thời giúp cán bộ kiểm lâm an tâm làm việc. Chính bởi vậy, cẩn có các cơ chế đông bộ đảm bảo thu hút nguôn nhân lực cho VQG Cát Tiên.

Cơ chế chia sẻ lợi ích phù hợp và dựa trên sự đồng thuận của người dân. Điều này đòi hỏi phải có các cơ chế giám sát và đánh giá phù hợp đảm bảo việc chia sẻ lợi ích có sự tham gia của các bên, đặc biệt là người dân. Việc rà soát và điều chỉnh cơ chế chia sẻ lợi ích hiện nay, xác định các tôn tại và thách thức dựa trên góc nhìn của người dân sẽ giúp hoàn thiện và nâng cao hiệu quả và tính công bằng của chính sách.

Hoàn thiện cơ chế khoán bảo vệ rừng. Mặc dù chính sách của Đảng và Nhà nước có định hướng rõ ràng trong Luật Lâm Nghiệp 2017 và Chiến lược phát triển lâm nghiệp giai đoạn 2021- 2030, tầm nhìn 2050 về việc khuyến khích sự tham gia của người dân vào công tác bảo tồn và phát triển rừng, việc hiện nay phần lớn các diện tích rừng 
đang do VQG tự quản lí chưa thể hiện rõ nét quan điểm này của Chính phủ. Mặc dù vậy, các diện tích VQG đã tự quản lí là các vùng trọng yếu có giá trị đa dạng sinh học cao và trước đó người dân quản lí không hiệu quả, việc thiếu hụt vế nguôn nhân lực như đã thảo luận ở trên không đảm bảo được tính hiệu quả của công tác này. Xây dựng các mô hình đồng quản lí giữa VQG và người dân trong tương lai là hết sức cân thiết.

\section{Xây dựng cơ chế giám sát và đánh giá có sự} tham gia của người dân. Giám sát và đánh giá là một trong những yếu tố cốt lõi của PFES để chứng minh tính điều kiện, bổ sung và hiệu quả của chính sách. Tuy nhiên như các phân trên của báo cáo đã trình bày, hiện nay sự sẵn có của số liệu cũng như nguồn lực và năng lực của $\mathrm{VQG}$ trong việc thu thập, lưu trữ và phân tích số liệu liên quan đến đánh giá tác động của PFES đối với sinh kế của người dân là rất hạn chế. Điều này đặt ra những thay đổi cả về chính sách ưu tiên và đâu tư dành cho xây dựng cơ sở dữ liệu và nâng cao năng lực của VQG trong công tác giám sát và đánh giá. Ngoài ra, cần đẩy mạnh hơn các hoạt động giám sát và đánh giá quá trình thực hiện chi trả. Nhiêu hộ dân tham gia phỏng vấn đã chia sẻ những bất cập trong việc theo dõi và giám sát chi trả. Tại cấp thôn, việc chấm công còn được coi là chưa hợp lí và minh bạch. Theo kết quả phỏng vấn với người dân tại Tà Lài chỉ ra sự cần thiết trong việc giám sát để đảm bảo các chương trình thực hiện phải đúng đối tượng chính sách chưa được thực hiện đây đủ. Xây dựng hệ thống phản hồi ý kiến như xây dựng đường hotline, hòm thư góp ý kiến và thuê giám sát độc lập cũng sẽ nâng cao hiệu quả thực hiện và tác động của PFES.

Thiết lập quy định liên quan đến việc lưu trũ̃ thông tin, số liệu. Mỗi đơn vị bâu ra đầu mối chuyên trách việc lưu trữ những số liệu và có quy định về việc chuyển giao số liệu một cách bài bản. Xây dựng quy chế phối hợp trong trao đổi thông tin, dữ liệu.

\subsection{Giải pháp hỗ trợ nguồn vốn xã hội}

Hài hòa hóa giữa chính sách hỗ trợ đồng bào dân tộc thiểu số với chính sách PFES hướng tới hiệu quả bảo vệ và phát triển rừng. Cần có sự hài hòa giữa chính sách xã hội và chính sách
PFES bởi hoạt động bảo vệ và phát triển rừng cần huy động nguôn lực của mọi thành viên trong cộng đông và việc chỉ tập trung vào một nhóm người yếu thế có thể làm suy giảm động lực cho các nhóm xã hội khác tham gia vào $\mathrm{PFES}$.

Kết hợp PFES với các chính sách hỗ trợ người nghèo. Theo kết quả nghiên cứu, tiêu chí hộ nghèo được coi là một trong những tiêu chí chính trong việc VQG và cộng đông đề xuất và lựa chọn tham gia hưởng lợi từ PFES. Cùng một lúc tại địa bàn nghiên cứu cũng có nhiều chương trình và dự án xóa đói giảm nghèo. Việc kết hợp PFES với các chương trình hỗ trợ người nghèo khác có thể tránh đầu tư dàn trải và kém hiệu quả, đồng thời tạo ra động lực lớn hơn cho người nghèo tham gia vào công tác bảo vệ rừng.

\subsection{Giải pháp hỗ trợ nguồn vốn tài chính}

Đa dạng hóa sinh kế cho người dân. Việc đa dạng sinh kế cho người dân mở rộng các nguôn thu phi nông nghiệp là hết sức cân thiết tại địa bàn này. Nguôn thu từ PFES có thể được xem xét và gợi ý cho việc xây dựng các mô hình sản xuất hiệu quả, kết nối thông tin và chia sẻ kinh nghiệm giữa các vùng đệm về các mô hình phát triển kinh tế hiệu quả và tổ chức đào tạo những kĩ năng cho người dân.

Mở rộng nguồn thu và nâng cao mức chi trả của PFES. Với cơ chế thị trường mà PFES đang hướng tới (người mua trả tiền cho dịch vụ họ cân) và quy định về mức thu đã được quy định trong Luật Lâm Nghiệp 2017, việc nâng cao mức chi trả PFES sẽ không thể diễn ra trong một tương lai gần. Tuy nhiên, việc mở rộng và kết hợp nguồn thu PFES áp dụng với các dịch vụ môi trường khác đang được đề cập trong quy định hiện hành ví dụ như dịch vụ các-bon sẽ có thể gia tăng nguôn thu để chi trả cho người dân. Ngoài ra, xây dựng các cơ chế chi trả cho các dịch vụ môi trường rừng quan trọng khác như bảo tôn đa dạng sinh học là cần thiết để nâng cao nguôn thu từ $\mathrm{PFES}$ cho Vườn quốc gia Cát Tiên nói riêng và các Vườn quốc gia khác nói chung.

Sử dụng PFES để tạo ra các quỹ tín dụng quy mô nhỏ. Tại nhiều địa phương trên cả nước (bao gồm Sơn La và Quảng Nam), tiền PFES trả về 
cộng đồng đã được sử dụng để xây dựng các mô hình tài chính và quỹ tín dụng quy mô nhỏ để cho các thành viên trong cộng đông được vay vốn và được coi là một trong những mô hình hiệu quả thúc đẩy sự tham gia của người dân. Tại VQG Cát Tiên, cho tới nay số tiền chủ yếu được chia đều cho người dân; vì vậy, việc xây dựng phương án sử dụng tiề PFES phù hợp để tạo ra các quỹ tín dụng quy mô sẽ nâng cao được tính hiệu quả của chính sách trong việc cải thiện sinh kế của người dân.

Xem xét lồng ghép PFES với bảo hiểm nông nghiệp để phòng tránh và giảm thiểu các rủi ro. Như kết quả báo cáo đã trình bày, người dân địa phương tại vùng nghiên cứu chịu nhiều rủi ro về thiên tai, mất mùa và thị trường bấp bênh nên đời sống rất bấp bênh. Hiện nay trên thế giới và tại Việt Nam, nhiều mô hình bảo hiểm nông nghiệp hỗ trợ người dân trong quá trình phòng tránh và giảm thiểu rủi ro đã được thực hiện (Baoviet, 2020; Tổng công ty cổ phân tái bảo hiểm quốc gia Việt Nam, 2020;
BaohiemBaoMinh, 2020). Hỗ trợ người dân tiếp cận thông tin với các chế này và khả năng sử dụng tiền nhận được từ PFES để tiếp cận các mô hình bảo hiểm này có thể giúp người dân đảm bảo nguồn sinh kế bền vững hơn.

Kết hợp giữa chi trả bằng tiền mặt và phi tiền mặt. Hiện nay phương thức chi trả từ PFES chủ yếu được thực hiện chi trả bằng tiền mặt tại Cát Tiên. Tuy nhiên, Pham et al. (2013) khi nghiên cứu các mô hình chi trả $P E S$ trên toàn câu và PFES tại Việt Nam đã nhận thấy sự kết hợp chi trả bằng tiền mặt và phi tiền mặt sẽ đem đến hiệu quả kinh tế và sinh kế lớn nhất. Các hộ dân ở Tiên Hoàng phỏng vấn cũng chỉ ra rằng số tiền PFES rất thấp nên không tạo được động lực kinh tế để tham gia vào bảo vệ và phát triển rừng. Tuy nhiên, họ cho rằng nếu nhận được PFES thông qua qua hình thức cây giống chất lượng cao thì sẽ tạo động lực với họ lớn hơn bởi với điều kiện tiếp cận thông tin và nguôn lực tài chính, người dân hiện khó có thể mua được các loại giống cây trông đảm bảo. 


\section{Kết luận}

Sau 10 năm thực hiện, Chính sách chi trả DVMTR đã tạo ra các tác động tích cực về mặt kinh tế và xã hội với phần lớn hộ tham gia khảo sát trong nghiên cứu này. Tuy nhiên, để nâng cao hiệu quả của chính sách PFES cần có cơ chế chia sẻ lợi ích phù hợp, thúc đẩy sự tham gia của người dân đông thời hài hòa hóa với các chính sách phát triển kinh tế xã hội khác. Nghiên cứu này đã giải quyết phần nào lỗ hổng kiến thức được đề cập và đưa ra các bằng chứng khoa học hiện có để chứng minh tác động thực sự của chi trả DVMTR đối với cải thiện sinh kế của hộ gia đình tại Vườn Quốc Gia Cát Tiên. Tuy nhiên, báo cáo này vẫn còn một số hạn chế nhất định như sự thiếu hụt trong tài liệu và số liệu liên quan đến chi trả DVMTR, việc chọn cặp thôn nghiên cứu chưa đạt được điều kiện lý tưởng nhất, nguôn lực tài chính và con người có hạn chính vì vậy hi vọng các nghiên cứu trong tương lai có thể xây dựng dựa trên cả kết quả và hạn chế của nghiên cứu này để tiếp tục hoàn thiện quá trình đánh giá tác động của chính sách. 


\section{Tài liệu tham khảo}

Angelsen, A., 2017. REDD+ as result-based aid: General lessons and bilateral agreements of Norway. Review of Development Economics, 21(2), 237-264

BaohiemBaoMinh, 2020. Bảo hiểm nông nghiệp $<$ https://www.baominh.com.vn/bao-hiemnong-nghiep $>$ [Ngày truy cập 16/11/2020].

Baoviet, 2020. Bảo hiểm nông nghiệp < https:// www.baoviet.com.vn/insurance/Duan-thi-diem/Bao-hiem-nong-nghiep/ PilotProjectLandingPage/39/> [Ngày truy cập 16/11/2020].

Bos, A. B., 2020. Richting een verbeterde evaluatie van subnationale initiatieven die tropischeontbossing verminderen. GeoInfo, 17(2), 40-41.

Duong, N. T. \& de Groot, W. T., 2018. Distributional risk in PFES: Exploring the concept in the Payment for Environmental Forest Services program, Vietnam. Forest Policy and Economics, 92, 22-32.

Duong, N. T. \& de Groot, W. T., 2020. The impact of payment for forest environmental services (PFES) on community-level forest management in Vietnam. Forest Policy and Economics, 113, 102135.

Haas, J. C. et al., 2019. How fair can incentivebased conservation get? The interdependence of distributional and contextual equity in Vietnam's payments for Forest Environmental Services program. Ecological Economics, 160, 205-214.

Le Velly, G., \& Dutilly, C., 2016. Evaluating payments for environmental services: Methodological challenges. PloS one, 11(2), e0149374.

Naeem, S., et al, 2015. Get the science right when paying for nature's services. Science, 347(6227), 1206-1207.

Nguyễn Chiến Cường, 2020. Chính sách chi trả DVMTR tại Việt Nam: Kết quả và định hướng giai đoạn 2021-2030. Bài trình bày tại
Hội thảo về Chính sách chi trả dịch vụ môi trường rừng ngập mặn tại Việt Nam. TP Hồ Chí Minh.

Phạm Thu Thủy và cộng sự, 2018a. Vai trò của chi trả dịch vu môi truiơng rüng trong hỗ trợ tài chính cho ngành lâm nghiệp Việt Nam (No. CIFOR Infobrief no. 228, p. 6p). Center for International Forestry Research (CIFOR), Bogor, Indonesia.

Sunderlin, W. D., \& Sills, E. O., 2012. REDD+ projects as a hybrid of old and new forest conservation approaches. Analysing REDD+: Challenges and choices, 31-50.

Sunderlin, W. D. et al., 2016. Technical guidelines for research on REDD+ subnational initiatives. CIFOR.

Tổng công ty cổ phần tái bảo hiểm quốc gia Việt Nam, 2020. Bộ Tài chính phê chuẩn sản phẩm Bảo hiểm Nông nghiệp < http://vinare.com.vn/vn/Tin-tuc-Su-kien/ Thong-Tin-Thi-Truong/Bo-Tai-chinhphe-chuan-san-pham-Bao-hiem-Nongnghiep.aspx> [Ngày truy cập 16/11/2020].

Trædal, L. T., \& Vedeld, P. O., 2017.

Livelihoods and land uses in environmental policy approaches: The case of PES and REDD+ in the Lam dong province of Vietnam. Forests, 8(2), 39.

Tran, T. T. H. et al., 2016. Payments for ecosystem services in Hoa Binh province, Vietnam: An institutional analysis. Ecosystem Services, 22, 83-93.

VNFF, 2020. Kiểm tra, giám sát đánh giá chi trả dịch vụ môi trường rừng. Bài trình bày của VNFF trong hội thảo "Tiếp cận đa bên trong giám sát, đánh giá chính sách chi trả dịch vụ môi trường rừng" tổ chức ngày 28/05/2020 tại Hà Nội.

Wunder, S., 2005. Payments for environmental services: Some nuts and bolts. Occassional Paper No.42. Bogor: CIFOR 

Các báo cáo chuyên đề của CIFOR chuyển giao các kết quả nghiên cứu quan trọng đối với ngành lâm nghiệp. Nội dung của báo cáo đều được đánh giá bởi các chuyên gia trong và ngoài tổ chức.

Nhằm bảo vệ diện tích rừng hiện có, nâng cao chất lượng rừng, gia tăng đóng góp của ngành Lâm nghiệp vào nền kinh tế quốc dân, giảm nhẹ gánh nặng lên ngân sách Nhà nước cho việc đầu tư vào ngành Lâm nghiệp và đảm bảo an sinh xã hội của người làm nghề rừng, Chính phủ Việt Nam đã quyết định thông qua cơ chế tài chính mới để huy động nguồn lực cho ngành Lâm nghiệp, đó là chính sách chi trả dịch vụ môi trường rừng - PFES. Mặc dù PFES được kì vọng sẽ giúp nhiều vườn quốc gia trên cả nước trong công tác bảo vệ phát triển rừng, có rất ít các bằng chứng khoa học được đưa ra để khẳng định tính hiệu quả của PFES trong lĩnh vực này. Sử dụng trường hợp nghiên cứu điểm tại Vườn Quốc Gia Cát Tiên, báo cáo này thảo luận tác động kinh tế và xã hội của chính sách Chi trả dịch vụ môi trường rừng (PFES) đối với các Vườn Quốc Gia tại Việt Nam.

\begin{tabular}{|c|c|c|}
\hline (1) & $\begin{array}{l}\text { RESEARCH } \\
\text { PROGRAM ON } \\
\text { Forests, Trees and } \\
\text { Agroforestry }\end{array}$ & $\begin{array}{l}\text { Chương trình nghiên cứu của CGIAR về Rừng, Cây gỗ và Nông lâm kết hợp (FTA) là chương trình phát triển } \\
\text { nghiên cứu lớn nhất thế giới nhằm nâng cao vai trò của rừng, cây gỗ và nông lâm kết hợp với mục tiêu } \\
\text { phát triển bên vững và đảm bảo lương thực để ứng phó với biến đổi khí hậu. CIFOR chủ tri các nghiên cứu } \\
\text { FTA trong mối quan hệ đối tác chiến lược với Bioversity International, CATIE, CIRAD, INBAR, ICRAF và TBI. }\end{array}$ \\
\hline & & Nghiên cứu này được hỗ trợ bởi Quỹ đối tác CGIAR: cigar.org/funders/ \\
\hline
\end{tabular}
nghiên cứu sáng tạo, nâng cao năng lực của các bên đối tác, tích cực tham gia đối thoại với các bên liên quan để hỗ trợ định hình chính sách và thực tiễn tác động tới rừng và con người. CIFOR là tổ chức nghiên cứu thuộc liên minh CGIAR và chủ trì các chương trình nghiên cứu của CGIAR về Rừng, Cây gỗ và Nông lâm kết hợp (FTA). Trụ sở chính của CIFOR đặt tại Bogor, Indonesia và các văn phòng của CIFOR có mặt tại Nairobi, Kenya; Yaounde, Cameroon; Lima, Peru và Bonn, Germany. 